\title{
Information Technology and Marketing - An Important Partnership for Decades
}

Jan Philipp Graesch ${ }^{\mathrm{a}, \mathrm{b}}$ and Prof. Dr. Susanne Hensel-Börner ${ }^{\mathrm{b}}$ and Prof. Dr. Jörg Henseler ${ }^{\mathrm{a}, \mathrm{c}, *}$

${ }^{a}$ Chair of Product-Market Relations, University of Twente, Enschede, the Netherlands

${ }^{b}$ Marketing \& Sales, Hamburg School of Business Administration, Hamburg, Germany

${ }^{c}$ Nova Information Management School, Universidade Nova de Lisboa, Portugal

*Corresponding author. E-Mail: j.henseler@utwente.nl

This is the author accepted manuscript version of the article published by

Emerald as:

Graesch, J. P., Hensel-Börner, S., \& Henseler, J. (2020). Information technology and marketing: an important partnership for decades. Industrial Management and Data Systems. [Advanced online publication on 3 November 2020]. Doi:

https://doi.org/10.1108/IMDS-08-2020-0510

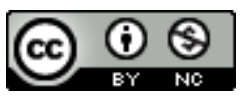

This work is licensed under a Creative Commons Attribution-NonCommercial 4.0 International License. 


\section{Information Technology and Marketing - An Important Partnership for Decades}

Purpose: The enabling technologies that emerged from information technology (IT) have had a considerable influence upon the development of marketing tools, and marketing has become digitalized by adopting these technologies over time. The purpose of this paper is to demonstrate the impacts of these enabling technologies on marketing tools in the past and present and to demonstrate their potential future. Furthermore, it provides guidance about the digital transformation occurring in marketing and the need to align of marketing and IT.

Design/methodology/approach: This study demonstrates the impact of enabling technologies on the subsequent marketing tools developed through a content analysis of information systems and marketing conference proceedings. It offers a fresh look at marketing's digital transformation over the last 40 years. Moreover, it initially applies the findings to a general digital transformation model from another field to verify its presence in marketing.

Findings: This paper identifies four eras within the digital marketing evolution and reveals insights into a potential fifth era. This chronological structure verifies the impact of IT on marketing tools and accordingly the digital transformation within marketing. IT has enabled digital marketing tools in all four digital transformation levers, i.e., automation, customer interaction, connectivity and data.

Originality: This study is the first to apply the digital transformation levers of automation, customer interaction, connectivity and data to the marketing discipline and contributes new insights by demonstrating the chronological development of a digital transformation in marketing over eras.

Practical implications: The sequencing of enabling technologies and subsequent marketing tools demonstrates the need to align marketing and IT to design new marketing tools that can be applied to customer interactions and be used to foster marketing control. 
Keywords: information technology; marketing; alignment; conceptual paper; content analysis; eras in digital marketing; levers of digital transformation; chronological marketing evolution

Paper type: Conceptual Paper

\section{Introduction}

Information technology (IT) and marketing are well-known disciplines and have been fields of research for many scholars. As a result of analyzing the current state of the literature, which has focused on dedicated segments and portions of the functions, it has become necessary to adopt a macro perspective and widen the view to observe the overall picture of the relationship between marketing and IT. Historically, in development economics, IT has been thought of as a key factor in marketing functions, and it plays an important role in the evolution of marketing through its increasing influence - or as it is generally called - the digital transformation. In contrast, it has been suggested that marketing is losing its influence within firms and has become marginalized because typical marketing decisions have moved to other departments, such as research and development, finance or strategy (Homburg et al. 2015; Verhoef and Leeflang 2009; Sisodia 2006). Moreover, it is apparent that marketing and sales managers do not always keep up with their digitally empowered customers (Day 2011). However, the use of IT tools and the flexibilities in IT infrastructures are factors contributing to customer interactions and business success in terms of creating and capturing value by managers (Drnevich and Croson 2013; Benitez et al. 2018; Domínguez-Escrig et al. 2018). Furthermore, IT is observed to not only advance marketing tools but also marketing methods by creating new enabling technologies. Hence, we have observed an urgent need to identify the new role of IT in conjunction with the continually changing roles of marketing. This new constellation and 
overlapping of roles and tasks between the disciplines is what we call alignment between marketing and IT.

So far, little attention has been paid to the roles of marketing and IT in combination. Since both disciplines are part of a company's value creation and support function, the question becomes apparent as to why firms separate marketing and IT from each other. Subsequently, a much debated question is whether IT is perceived as a firm's cost or investment (Verhoef and Leeflang 2009). Following the evolution of marketing and its tools in particular, the need for IT integration turns out to be inherently important. To achieve efficient use of IT and the right fit with it, marketing managers need to know how to make use of IT-enabled marketing tools. Thus, support from and alignment with the IT discipline appears essential for marketing managers. Therefore, future marketing tools could be directly shaped to meet the needs and evolved in a shorter period of time if marketing and IT were to collaborate more closely; we believe there is evidence for the creation of even more efficient IT-enabled marketing tools if these disciplines join forces.

The enabling technologies that emerge from the IT environment substantially impact the development of marketing tools and methods (Feng et al. 2020). Marketing finds itself in the middle of a digital transformation, which IT has caused and accelerated over time. Practical examples of technologies that enabled marketing tools are the following: database management systems enabled customer relationship management (CRM) tools; internet websites enabled online marketplaces; social media applications enabled corporate influencers and so on. However, consumers were using many of these technologies even before they were used as marketing tools. Online forums (Murray and Maceli 2017), mobile apps (Taylor et al. 2015) and social media websites (Bauer et al. 2015) are examples of technologies that marketing currently uses 
as tools but that originated as user-to-user communication. Ultimately, new marketing domains such as digital (content) marketing (Saura et al. 2017; Kim 2015) and influencer marketing (Wiedmann and Mettenheim 2020), arose naturally from these technologies. Hence, IT has essentially revolutionized marketing methods by increasing marketing performance, reach and efficiency.

Researchers have studied digitally empowered marketing over a certain period, focusing on many aspects and details. Intensified competition, opportunities and changing customer purchasing behavior (Ianenko et al. 2019) have increased the need for academic attention. Recently, researchers have shown a growing interest in the alignment of the IT function (Ricciardi et al. 2017; Domínguez-Escrig et al. 2018) and its strategy (Coltman et al. 2015; Gerow et al. 2014; Bharadwaj et al. 2013) within the organization but have rarely focused on marketing functions. Some scholars underline the demand for a more innovative marketing department (Verhoef and Leeflang 2010), reduce innovation barriers (Maldonado-Guzmán et al. 2017) and there is ample research about the relationship between marketing and other major functions besides IT (Dewsnap and Jobber 2000). Further, academia still lacks guidance on how to align IT within the organization (Matt et al. 2015; Coltman et al. 2015), and additionally, the marketing department's capability gap in terms of digitalization needs future research (Day 2011). Moreover, scholars have found that the marketing department has been marginalized and has lost significant influence because typical marketing decisions have moved to other departments (Homburg et al. 2015; Sisodia 2006) and are influenced by the customer. Conclusively, the concept of digitally empowered marketing and the need for alignment between IT and marketing are central to both academia and applied praxis. 
This study systematically identifies the sequencing of enabling technologies followed by marketing tools and the establishment of marketing domains by performing a content analysis of conference proceedings over the last 40 years. As a complete list is out of reach, we will focus on the most relevant conferences within both disciplines, which are as follows: The International Conference on Information Systems (ICIS) (AIS 2020a) and the Academy of Marketing Science annual conferences (AMS 2020). These sequences have been clustered in Table 1 and are surrounded by the marketing domains. The results are part of a framework of digital transformation in marketing. Furthermore, this study initially identifies four eras, i.e., the Telecommunication Era, Data-Managed Internet Marketing Era, User-Enabled Mobile Era, and Intelligent Networking Era, in which these sequences have occurred and provides insights about a potential fifth era, which we call the Autonomous IT Era. To show coherence and the evolving need for alignment, a brief overview of the history of the evolution of marketing will first be provided. This study is the first to apply digital transformation levers from other disciplines to the marketing discipline. The levers automation, data deployment, connectivity and improved customer interaction create essential clusters within the digital transformation, and we identified IT-enabled marketing tools in all four levers (Berger 2015). We will conclude by examining the implications for academic research and marketing managers in terms of marketing and IT alignment.

\section{Marketing evolution}

Let us start the evolution with the following simple question: what is the task of marketing and sales? If we had asked the same question 20 to 40 years ago, we probably would have received a different answer from today. Moreover, were we to ask this question 20 years in the future, we might obtain the following counterquestion: why do we need marketing or sales people? Through digitalization and individualization, 
customers become increasingly autonomous and can handle most of their sourcing without relying on one point of contact with a salesperson or marketingperson. Moreover, researchers have even found an automation potential of sales tasks of approximately 40 percent (Muro et al. 2019). Subsequently, we need to discover what has changed in marketing in recent years and determine what marketing is all about currently and what it will potentially be in the future.

Hence, in recent decades, the applied managerial discipline and marketing practices have undergone significant changes, from their earlier focus on mass marketing followed by the industrial revolution in Western industrialized countries and moving toward segment marketing (Borch 1957; Mallen 1975). Segment marketing is different from mass marketing in that businesses focus on the wants and needs of the "average" customer, identifying specific segments and using marketing as a planning tool (van Waterschoot and van den Bulte 1992). Thus, scholars have long speculated that the future of managerial marketing should focus on customer-centricity rather than the average customer within a market segment (Sheth et al. 2000), and there are several new approaches to a customer-centric marketing mix that increase customer participation (Sheth and Sisodia 2012; Wu and Li 2018). More current marketing mix approaches focus on web-based aspects, which have emerged as a consequence of various changes stemming from new types of customers, global competition and rapid development in technologies (Vassileva 2017). As in the previous marketing systems, customers are still the center of marketing activities, with the difference being that the market is operated within a cybernetic marketing system in which customer activities and business transactions can be monitored in real time (Dholakia et al. 2011). Observing this evolution, researchers point to content marketing to meet individual customer needs (Järvinen and Karjaluoto 2015; Chaffey and Smith 2013). To 
summarize, marketing has changed from mass marketing to personalized marketing and now uses web tools as marketing tools for customer communication.

Due to the increasing demand for digital tools, further insights are required to solve the question of responsibilities. The responsibilities of new roles, e.g., the chief digital officer, who is connected to planning and deployment of digital transformation strategies, is unclear because functional interdisciplinary roles contradict with those of siloed disciplinary executives (Singh and Hess 2017). However, these new roles can lead to new possibilities in the use of digital tools. The possibilities that IT can offer are obviously much larger than marketing can identify, let alone implement. Surprisingly, the extent to which the IT department is already aligned with marketing and sales activities and decisions has not been a field of research so far. In conclusion, this imbalance between quickly increasing IT functionalities and the need to develop digital competency in the marketing department underlines the need for alignment between marketing and IT.

\section{The influence of IT within the marketing discipline}

Digitalization has introduced many IT technologies and tools, which fundamentally affected the marketing and sales functions when they were applied. This study analyzes and summarizes examples of these enabling technologies and tools accordingly. Some tools had a major impact on the marketing function and even helped in the creation of new marketing domains, which would have not been established without IT support.

Following the expected sequencing between enabling technologies and marketing tools, we will first provide a chronological overview of these analyzed components and then a structured framework that explains the interrelationship between these components. For the chronological overview, we will provide a table focusing on enabling technologies and convert the table data into chronical eras because marketing 
technologies arose from different enabling technologies in parallel. Furthermore, for a structure, we will use the levers data, connectivity, automation and customer interaction because these indicate digital transformation. Hence, we will cluster the analyzed components into these four levers.

\section{Method}

To demonstrate the correlation and development of enabling technologies and the subsequent marketing tools, we aim for a chronological list. However, the field of enabling technologies and the use of marketing tools is broad. Consequently, a complete list is out of reach, and reviewing every side would be unwieldy. Thus, it is appropriate to focus on the most relevant aspects. As the exact point of time of the development of enabling technologies is not important, but rather the sequencing between both is the subject of this research, we decided to perform a qualitative content analysis of conference proceedings and focus on two relevant conferences. The International Conference on Information Systems (ICIS), which has a history of over 40 years with approximately 270 conference papers published yearly that are primarily delivered by and for academics, can be understood as a relevant IT conference (AIS 2020a). ${ }^{1}$ To add marketing's perspective, we chose the Academy of Marketing Science (AMS) annual conference, due to its reputation in the marketing scientific community, a history of over 40 years and a yearly publication volume of between 100 and 330 conference papers (AMS 2020). These two conferences build the basis for the analysis of this study.

${ }^{1}$ In exceptional cases other conferences have been used when the gap between first entry of ICIS deviates significantly from other conferences. Deviations are clearly displayed within Table 1. 
The conference proceedings were studied using a qualitative content analysis as follows. We chronologically screened the titles and keywords of the ICIS conference proceeding papers (AIS 2020b) starting from 1980, as this is when the first available source for new technologies and terms corresponding to marketing was found. Furthermore, we added the earliest available reference for each new technology into Table 1. This same procedure was applied to that of the AMS annual conference proceedings starting from 1979, which were published from 2015 onwards (e.g., Gitlow and Wheatley 2016). Then, we screened the titles of the marketing conference papers for terms such as electronic and digital plus online and recorded the corresponding papers in Table 1 as well. Then, we determined whether the papers fit into the context by analyzing all the abstracts and excluding inappropriate topics accordingly, as well as duplicates. For example, papers dealing with the marketing of mobile phones were excluded because mobile phones could be replaced by any other innovative good, so we focus on marketing with and by mobile technologies. Finally, we determined the marketing domains as such if a journal within the Scopus database contains the term in the title (Elsevier 2020; Henseler and Guerreiro 2020). Additionally, we added marketing domains that were published with definitions for marketing types stated by the American Marketing Association (AMA 2020). Conclusively, with this method we categorically identified the IT enabling technologies, followed by the marketing tools and marketing domains.

\section{Results}

The results of this study are manifold. First, we identified 28 enabling technologies, 103 marketing tools and 8 overarching marketing domains. Second, the study identifies the chronological eras containing these components. Finally, we provide a structure that explains the interrelationship of these components. 
Table 1 shows the marketing tools that emerged from the enabling technologies, clustered by marketing domains, if applicable, and sorted chronologically. One aspect we aimed to identify was the developed marketing domains, which are demonstrated in this table.

[Insert Table 1 near here]

Some tools and technologies from different domains are constructed with dependencies between each other and appear approximately at the same time. However, following the chronological appearance of the technologies and tools, we clustered those into four consecutive eras, as shown in Figure 1. We have named the four identified eras the Telecommunication Era, the Data-Managed Internet Marketing Era, the User-Enabled Mobile Era, and the Intelligent Networking Era and have derived insights about a potential fifth era, which we call the Autonomous IT Era. As shown in Figure 1, we have identified a chronological overlap of the eras and understand the demonstrated periods as approximated time spans.

[Insert Figure 1 near here]

\section{Telecommunication Era}

Marketing tools in the early 1980s used telephones as an enabling technology. Telecommunication in private homes started early but slowly (Hopner 1961) and was used for selling and shopping, such as through cold calls and catalog ordering in the '80s (George 2015) and enhanced with telemarketing in the 1990s. Furthermore, speech understanding systems (Kawahara et al. 1996) enabled the use of an access-automated call center, where customers could identify and guide themselves to the responsible salesperson (Ehrlich et al. 1997). The call centers (Wang et al. 2015) were further improved by integrating technologies of the later eras (Subramanyam and Krishnan 
2001).

We identified this era as occurring between 1980 and 1995.

\section{Success stories within the Telecommunication Era}

To finalize, we provide a few examples of marketing tools applied in the business context. For instance, Novell, the former world's leader in networking, served close to 50 percent of the world's population in 11 markets. They gained this outstanding performance with advanced call centers as the only way to support this rapid growth (Costa 1996; Fleischer 2004). Even more interesting is that the return on investment for call centers has been identified as being greater than 20 percent. Furthermore, the W. Wrigley Jr. Company, the world's most widely known chewing gum producer, was able to reduce their sales costs by 1.4 percentage points by installing call centers (Prabhaker et al. 1997).

\section{Data-Managed Internet Marketing Era}

The second era includes technologies that enabled mainly data-based marketing and firm-to-customer connectivity. IT brought enabling technologies that supported the corporation in structuring information, for example, with data management systems (Sarda 1987), enterprise resource planning (ERP) (Veth et al. 1998), neuronal networks (Schocken 1990) and knowledge management systems (Kumar 1990). Furthermore, the marketing reach was increased via e-mail communication (El-Shinnawy and Markus 1992). With the internet as the most visible manifestation of this era, the company increased its ability to communicate with and collect information about and analyze their customers (Rust 2020). Further, marketers could communicate proactively (webpages) and reactively (electronic commerce) without being manually involved in the marketing process. Thus, electronic commerce (e-commerce) with its internet 
advertising was established (Ives et al. 1995; Löbbecke and Powell 1997; Sautter and Lindquist 2015). Global sales and marketing were further enabled by using IT systems with a worldwide reach. Subsequently, customers used tools such as online marketplaces, electronic catalogs, online auctions and virtual stores to reach their suppliers (Dellarocas and Klein 1999; Vakrat and Seidmann 1999; Yang 2015; Gonzalez 2015; Diehl and Weinberg 2015). Similar tools followed in the B2B environment (Yoo et al. 2001; Boyd and Spekman 2015). Hence, a firm's sales power could be tremendously increased without expanding the sales and marketing workforce. However, to use the provided IT solution efficiently, training is necessary to address the services sold and the customer messages correctly.

We have identified that this era occurred between 1990 and 2005, which introduced new marketing domains such as online marketing and internet marketing (Zugelder et al. 2015).

Success stories within the Data-Managed Internet Marketing Era

Walmart, one of the largest brick and mortar retailers within the U.S., served 244 million customers online each week in 2014. Customers ordering online can rely on real-time estimated delivery dates. Walmart increased their global e-commerce sales by approximately 12 percent to $\$ 13.7$ billion in 2016 and has spent billions of dollars on technological investments, making it one of the largest IT spenders in the entire world, competing with Amazon (Ignatius 2017; Mohammed 2015; Yohn 2017).

$\mathrm{H} \& \mathrm{M}$ increased its sales revenues by 24 percent by integrating online and in-store shopping via services that enable shoppers to pick up and return online orders in the store while also offering more flexible payment options, faster delivery and improved search features. Further, H\&M increase their revenue via functionalities within digital 
tools such as search engines to find outfits worn by celebrities, where H\&M links similar clothes in their online shop (Hennes \& Mauritz AB 2020; Mulier 2019).

\section{User-Enabled Mobile Era}

In contrast to the Data-Managed Internet Marketing Era, where the corporation was using IT to reach and re-educate the customer, in the User-Enabled Mobile Era, it is the customer who gained influence through new IT solutions. In early 2000, webpages transformed from a passive medium to an active medium, where user-generated content (UGC), social media and electronic word of mouth (eWOM) became apparent (Koskinen 2003; Oh et al. 2008; Xu and Zhang 2009; Bussière 2015; Lo and Lin 2010). Customers could interact easily with other customers by using blogs and online communities (Xu and Zhang 2009; Landry et al. 2015). These new possibilities were also used in the corporate context, such as sharing online reviews, ratings, discussing service problems in forums and commenting online (Coussement and Antioco 2015; Murray and Maceli 2017; Chen et al. 2004; Mills et al. 2015; Yang Shuiqing et al. 2019). This has led to a change in sales and marketing responsibilities. Previously, the customer would consult the sales manager regarding the quality and nature of the product/service. Today, customers gather information from other customers via IT tools, such as blogs, social media and reviews to consider their purchase and later share their experiences with other customers using the same tools.

It seems to be inherent that the corporation needs to incorporate those techniques to gain control of sales again. Inevitably, marketing needs to align with IT to close this gap of control. However, surprisingly, firm-generated content, social media ads and purchase features in social media applications followed later, in approximately 2015 (Bacile et al. 2017; Guo et al. 2017; Dyrby et al. 2014). Specifically, firms exploit social media for marketing purposes by using it as an influential tool; they may pay customers to 
promote products from user to user or sponsor blog posts of celebrities (Gomez et al. 2018; Ferreira 2017; Segev et al. 2015; Geng et al. 2020). This interactivity and information sharing were positively associated with customer satisfaction (Shao et al. 2020).

Corresponding to this era, firms proactively invite customers to participate in innovation and new product development processes. IT-enabled cocreation allows the consumer to provide ideas, make demands or vote for product features (Grace et al. 2008; Emrich and Rudolph 2015; Hughes et al. 2015). Moreover, marketing departments made use of digital payment methods for collecting funding capital from potential customers by using crowdfunding as a tool (Zvilichovsky et al. 2013; Boeuf and Durivage 2016; Morgan and Obal 2016).

Furthermore, enabling technologies such as web caching and click-path-data support marketing through data mining and online login data by which pricing can be adjusted dynamically and websites can be improved based on click data (Hosanagar et al. 2002; Weinmann et al. 2013; Reid 2000; Yada et al. 2015; Chung 2015). These marketing tools are examples that have been further developed from former eras over time, indicating the overlap of the eras, as shown in Figure 1.

Further developments during this era are the invention of mobile applications and self-service technologies as enablers (Kemper and Wolf 2002; Bodendorf and Saueressig 2000; Treiblmaier and Dickinger 2006). This has led to new marketing channels such as mobile marketing and advertising and new service methods such as freemium content and digital coupons and ultimately to mobile shopping and mobile commerce (Goh et al. 2009; Guo et al. 2010; Nakhata 2015; Liu et al. 2007; Swilley and Cowart 2015; Han et al. 2013). Furthermore, the customer can fulfill services now on his own via self-services, whether mobile (e.g., mobile banking), in shops (e.g., self- 
scanning devices, ATMs) or as a remote service (Nel et al. 2015; Anitsal et al. 2015;

Espina and Pérez 2015; Paluch 2015).

We have identified that this User-Enabled Mobile Era, which brought new marketing domains, such as mobile marketing, social media marketing and influencer marketing, occurred between 2000 and 2015 (Bauer et al. 2015; Wiedmann and Mettenheim 2020).

Success stories within the User-Enabled Mobile Era

The success stories that involve the use of social media are assorted, for example, when Starbucks used Instagram to promote their Unicorn Frappuccino, their revenue increased by 3 percent globally and Fortune Magazine named Starbucks the fifth-most admired brand in the world (Gallaugher and Ransbotham 2010; Krishna 2018; Taecharungroj 2017).

Likewise, during a social media campaign, the International House of Pancakes (IHOP) changed its name to International House of Burgers (IHOb) for a short period in the summer of 2018, and over 30,000 users responded. IHOP's social media relevance improved after the announcement, and the number of burgers sold increased by 400 percent as a result of social media marketing (Odell 2018).

Tesla Motor CEO Elon Musk uses Twitter as the firm's main marketing channel. Via his regular tweets, he achieved the establishment of Tesla as the car brand most linked to topics such as electric cars and autonomous vehicles on social media, leaving behind the biggest electronic car producer, Renault-Nissan. Compared with the marketing spending necessary for professional corporate social media posts, Elon Musk outperformed his competitors by mainly using Twitter (Furr and Dyer 2020; Hansen 2015; Popkin 2018). 
Using the enabling technologies of self-service devices, McDonald's generated close to 5-6 percent more revenue by establishing 8,000 to 9,000 self-service kiosks, where customers can select their food on touch screens. McDonald's recognized that by allowing customers to visualize and touch the desired food, customers tended to select more items than at the usual counter. In parallel, the number of necessary personnel could be reduced (Zhu and Meyer 2017; Gavett 2015; Horovitz 2018).

Hence, creative social media statements and applied self-service support improve sales and marketing activities.

\section{Intelligent Networking Era}

In this last era, we have recognized tools that use new connected data and collaboration. At the end of the 2000s, the first machine learning algorithms were established, followed by artificial intelligence (AI) and web analytics in general (Ichise 2008; Keller et al. 2014; Tremblay et al. 2018). These technologies have enabled the marketing departments of firms to start predicting sales performances better, use automated analysis of text content, implement robo-advisory, personalize advertising in online environments and improve dynamic pricing (Boso et al. 2015; Fukawa and Huang 2018; Beser et al. 2019; Fresneda and Gefen 2017; Gironda and Korgaonkar 2016; Belanche et al. 2019). Due to big data technology sources, the tools' efficiency could be further improved (Zhang et al. 2014), and by using customers provided data, such as the customer's location and heart rate gained through the use of wearable technologies, marketing could be further personalized to individual consumers (Paramonov et al. 2013; Yuksel and Milne 2016; Frank et al. 2017). The usable amount of data and technologies that can create data and process data boomed during this era and increased networking. 
Further, machines were connected to cloud servers and the internet, which is called the internet of things (IOT), and supplies could be ordered without the necessary interaction of a user (Chmaj and Selvaraj 2015; Anwar 2018). Cloud infrastructures have made data globally available and allow marketing to use mobile CRM and automated sales force tools (Püschel and Neumann 2009; Töllinen et al. 2015; Karjaluoto et al. 2015; Karjaluoto et al. 2014). Databases were improved fundamentally by blockchain technologies that brought cryptocurrencies into webshops in addition to supplying cyber security, which enhanced the overall trade performance (Avital et al. 2016; Mauri et al. 2018; Chang et al. 2019). The field of marketing expanded via IOT, clouds and blockchain to a new area, in which new possibilities for revenue were obtained. In conclusion, this era improved existing tools with new intelligence and developed new tools in the virtual environment.

With further developments in hardware and software, augmented reality (AR) and virtual reality (VR) became possible, and marketing uses those technologies to present products to customers, by offering 3D virtual shopping tours or arranging virtual trade shows (Liu et al. 2007; Blazauskas et al. 2017; Poushneh 2017; Mann et al. 2015; Gabisch 2015). Additionally, virtual reality enables customers to obtain a better understanding of the form and usage of products and helps marketing explain the benefits of even those products that are still in development.

We have identified this era as starting in approximately 2010, and we believe it is still developing, which also means that complete new marketing domains have not yet emerged. We assign the described marketing tools to the domains of marketing analytics and technology marketing, as well as digital marketing. 


\section{Success stories within the Intelligent Networking Era}

There are various success stories using intelligent tools and networks. For example, Target Corporation, an American retail corporation, provides a mobile application (app) with over 27 million users. The application uses voice recognition, $\mathrm{AR}, \mathrm{VR}$ and $\mathrm{AI}$ and is one of Target's main personalization and customer loyalty tools. The app is also a source for insights into user preferences, behavior trends, and shopping habits. Through Target's digital efforts, the retailer increased its sales revenue and gained new customers (Bowler and Datar 2017; Srinivasan and Chen 2019). Sephora's mobile app also uses AR and AI and provides a feature where customers can virtually try on make-up. Sephora is able to track customers' preferences online and offline and has doubled its mobile sales each year (Bornstein and McGinn 2014). Furthermore, Nike reported a 30 percent rise in revenue in their running division as of 2012, which they ascribe to a new digital tool. This mobile application connects with a sensor installed in running shoes to monitor the user's speed, distance traveled and calories burned. Nike expanded this technology to other activities, such as playing basketball and sleeping (Gupta 2013).

Walmart uses artificial intelligence to automate their inventory with a robot scanning process in combination with electronic shelf labeling. This process automatically identifies out-of-stock refills and poorly selling units; as a result, Walmart can adjust its prices and promotions accordingly. Through this measure, Walmart aims to improve their pricing accuracy and product availability by a potential further twelve percentage points. Furthermore, Walmart plans to offer online ordered pick-ups in designated car parking lots with a maximum waiting time of three minutes (Dowd 2019; Rebholz 2019; Iansiti and Lakhani 2020).

With the use of blockchain, further opportunities are within reach. For example, shipping companies, such as Maersk, have used blockchain technologies, and (online) 
retailers such as Walmart and Alibaba track the location of their shipments in real time and record data such as temperature and customs documents. Blockchain will help to track goods more efficiently, reduce fraud and secure sensible data with expected savings of a billion dollars per year (Lal and Johnson 2018).

With the use of big data technologies, corporations can adjust their measures to target smaller segments and even at granular levels. Companies can analyze the data for each invoice and cluster it by product, package, customer group, etc. An average profitmargin lift of three to eight percent by setting prices at much more granular product levels could be achieved. The use of big data analyses combined with adequate resources in sales and marketing could increase profit margins by 20 percent (Baker et al. 2014).

In an attempt to implement UGC, Boeing started its own corporate blog but blocked all kinds of UGC, such as comments and feedback, with the result that customers perceived the blog as purely an advertising measure (Kaplan and Haenlein 2010). On the other hand, Boeing invited airlines to be part of the design process and incorporated airlines' needs accordingly. Furthermore, General Electric established a cocreation process as well as provided customers with access to tools and a library. Therefore, General Electric can outsource research efforts and risks to their customers and generate an environment with benefits for both parties (Prahalad and Ramaswamy 2004). Those examples show a variety of marketing tools using blockchain, virtual environments and cocreation with positive impacts on business performance.

\section{Autonomous IT Era?}

We also identified technologies in the conference proceedings that have not yet enabled marketing tools. These technologies might change consumers' habits and enable new marketing tools in the future. Furthermore, we studied the current trends in managerial 
magazines to speculate about a potential fifth era.

In the manufacturing sector, marketplaces currently focus primarily on the direct purchase of standardized products. However, the development of additive manufacturing changes this logic, giving firms the opportunity to trade 3D-printing capacities instead of goods. This exchange allows firms to enhance their profits and lower risks by marketing their printing capacities. Such sharing of production capacities instantiates an open production system (Stein et al. 2019). These 3D printing production systems gain untapped business opportunities by applying blockchain technologies. Blockchain can help businesses overcome intellectual property and data security barriers. Further, new business models such as secure design marketplaces and shared factories will be possible. Businesses could also offer additional services around 3D printing and offer less costly and more customized products across different stages of adoption (Klöckner et al. 2020; Chaudhuri et al. 2019). Sustainability will drive additive manufacturing even further because it reduces emissions during transportation and warehousing, packaging and waste. Furthermore, a recycling industry around additives will increase the sustainability of 3D printing and increase the acceptance of this technology among consumers and society. Hence, marketing will need to allocate a completely new digital market where customers do not buy physical goods but design instructions for 3D printers instead (Garmulewicz et al. 2018).

Additionally, neuronal networks will become more enhanced through augmented intelligence and classification technology, whereas devices can react in shorter periods to circumstances and expand the range of applications where classification technology can be used. However, during this era, devices will not compete with human thinking (Byrum 2019). Augmented intelligence can complement multipurpose hardware and adapt to a given task. This means that machines can react to 
the parameters of sensors, e.g., of a wearable device, and anticipate a reaction automatically. This will enable a closer human-computer interaction and aim for realworld processes in IT (Krenzer et al. 2019). Furthermore, automated planning and intelligent (semi)automated construction of processes will become possible in the form of human-automation hybrid work (Asatiani et al. 2019; Schön 2019). These technological developments will enable marketing to gain more information through, e.g., the parameters of wearable devices and apply marketing methods based on augmented intelligence to individual customers.

Moreover, 6G data connectivity will enable further opportunities such as smart implants and autonomous systems. Temporary hotspots served by drone-carried base stations or tethered balloons will improve mobility (Saad et al. 2019). This will support the use of mobile streaming and decrease the use of stationed screens such as TVs. On the one hand, this will affect TV advertising and decrease its importance, but on the other hand, screen presence and the emotions of the customer can be tracked precisely, e.g., by face recognition technologies in mobile devices (Guo et al. 2019).

Furthermore, systems that use predictive models to make automated decisions will increase and become more precise by using more variables (Fernandez et al. 2019). They can, for example, be used to predict credit scores (Zhou 2017). Prediction will enable marketing to analyze what will appeal to customers, improve operations and provide support in making products better. Furthermore, it can be used to improve search engine advertisements and provide customers with product suggestions when typing related words (Agrawal et al. 2020). Thus, this prediction ability will enhance marketing tools by foreseeing customer demands and preferences.

The use of RFID systems during supermarket shopping will bring new insights in terms of shelf stock and logistics but will also open the possibility of simplifying the 
customer checkout process in physical supermarkets (Wu et al. 2019). For example, automated gates will identify the contents of full shopping baskets by having customers just walk past; thus, customers can pay for all the items in their carts without scanning them separately.

The method of transportation will change significantly, either to autonomous vehicles, which have the potential to transform urban landscapes, existing transport systems and networks, or to lower car ownership by increasing car sharing (Legacy et al. 2019). In both cases, the number of customer-owned transportation vehicles will decrease significantly. Sharing cars and tracking customers by using new transportation methods will enable marketing to gain new marketing tools that are not limited to location- and time-adjusted advertisements but will also enable a firm to drive the customer with an autonomous car to a specific shop. In conclusion, we expect more marketing tools related to system intelligence, which can be used for (automated) customer interaction.

\section{Structured framework of the analyzed components}

To place the enabling technologies and marketing tools in the context of the digital transformation, a structured framework that explains the relations between the analyzed components is required. Thus, we have transferred Table 1 into Figure 2 and have included additional information, as explained in the following text.

The digital transformation incorporates the following four major levers: new data, connectivity, automation and digital customer interaction. Each lever is supported by propositions and enablers (Berger 2015). In this study, we apply the enabling technologies hereto and marketing tools and methods as propositions. The lever of data contains the availability and processing of existing and new data. Automation includes computer-aided support and self-service functionalities as well as the combination of 
data with algorithms. The connectivity lever contains the underlying functionalities of networking and data synchronization. The digitalized customer interaction lever covers the direct and indirect marketing applied to customers. It is driven by developments within the other levers, which may be understood as prerequisites. The marketing digital transformation blends perfectly into these stated four levers.

We classified the identified enabling technologies and marketing tools into these levers accordingly, as demonstrated in Figure 2. This visualization supports the statement that the influence of IT within marketing is manifold and contributes to several aspects of marketing. As demonstrated by Figure 2, we find in each of the four levers essential enabling technologies and marketing tools. This figure directly shows that marketing tools are not only concerned with customer interaction but also with customer management and investigation, as in the data lever. It refers to the use of data to inform and optimize the ways through which marketing managers interact with customers (Kumar et al. 2013). Furthermore, the figure demonstrates that an underlying connectivity is essential to reach out to customers. In the lever of automation, we find tools that can take over marketing actions and support in visualization. We found that digital transformation is inherent not only in firms but also in essential functions such as marketing. The profound influence of IT-enabling technologies led to marketing domains, which surround several marketing tools. The marketing domains are visualized as the outer circular lines in Figure 2. They demonstrate that marketing domains can include more than one digital transformation lever, e.g., relationship marketing or online marketing. In this study, we confirm three major aspects. First, digital transformation prevails in marketing according to the stated levers, i.e., data, connectivity, automation and digital customer interaction; second, marketing tools 
follow in sequence the enabling IT technologies; and third, marketing domains arise consequently and independently from the digital transformation levers.

[Insert Figure 2 near here]

By widen the view, as suggested in the beginning, the picture picture of how digital transformation affects marketing becomes comprehensible. However, the totality of what it means is more than the aggregate of its presumable contexts. Marketing tools make use of different technologies, even in combination with different technologies and occasionally in different ways than they were intentionally designed. IT and marketing together must understand the dynamics of the different meanings and uses for the designed tools and technologies. Krippendorff (1989) discovered that design is the key to giving things a sense, but in reality, things can be used for different purposes and will substitute for other things, which brings no significant difference. Hence, e-mails, telefaxes and telephones are, for example, substitutes for written letters and have reduced postal service activity. Moreover, social media are substitutes for the need for e-mails and phone calls. If the old technologies cannot compete against new technologies, the marketing tools using the old technologies will consequently lose their effectiveness. For example, social media marketing is currently much more efficient than newsletters, although the amount and the degree of details are higher in e-mails. However, understanding the advantages of the individual platforms that customers are using and perceiving as useful is essential to applying social media marketing campaigns efficiently (Kumar et al. 2013; Lacka and Yip 2018). Marketing and IT need to understand that they are dependent on each other. Therefore, marketing and IT have to interact like an aligned design team if they want to stay in control of customer interactions. 


\section{Conclusion}

Even though marketing is a well-known discipline and has been explored for decades, this paper is the first to demonstrate the digital transformation by applying the four levers of new data, connectivity, automation and digital customer interaction (Berger 2015) to enabling technologies and in sequence following marketing tools. Furthermore, this paper contributes new insights by demonstrating the chronological development of the digital transformation in marketing. We underline this by identifying four existing eras, which are named the Telecommunication Era, the Data-Managed Internet Marketing Era, the User-Enabled Mobile Era, and the Intelligent Networking Era, and providing insights into a potential fifth era, which we call the Autonomous IT Era. Strong marketing research can be used as a basis for several aspects within this topic; however, the combination of those topics leads to a new complex perspective.

This study has confirmed the occurrence of digital transformation in marketing and that marketing tools are dependent on IT developments. We have achieved this by presenting the historical development of enabling technologies and demonstrating how marketing tools followed them in sequence by giving examples. Further, we have identified the eras, which are named the Telecommunication Era, the Data-Managed Internet Marketing Era, the User-Enabled Mobile Era, and the Intelligent Networking Era and described their impact on marketing accomplishments. To prove the inherent digital transformation in marketing, we initially introduced a general model from another field to the marketing discipline (e.g., Berger 2015) and applied the four major levers, i.e., new data, connectivity, automation and digital customer interaction to the identified technologies and marketing tools as enablers and prepositions. As a result, we conclude that marketing and IT should work together to design new marketing tools, which can be applied to facilitate customer interactions and foster marketing control. By 
this measure, both parties will ensure that marketing will have the capabilities to use the tools efficiently. During the design phase of developing the marketing tools, we note that technologies and tools are more than just artifacts and can be used for different purposes that might substitute for existing tools (Krippendorff 1989). This study has raised important questions and provided guidance about the nature of the digital transformation in marketing and the need for alignment with IT.

\section{Outlook and limitations}

Regarding the outlook of marketing and IT alignment, we would like to emphasize certain aspects that surround the present study. The creation and use of (digital) marketing tools originated from the desire to acquire and retain consumers. In conclusion, it will be important to understand their effect and efficiency from a customer point of view (Lacka and Yip 2018). Hence, it is important to include the customer in the marketing tool design process. Furthermore, throughout the customer purchasing process, there might be several touchpoints between marketing and the customer via marketing tools (Edelman and Singer 2015; Lemon and Verhoef 2016). Due to the digital transformation, we expect customer touchpoints that are not or are hardly under the control of marketing. There is a compelling need for marketing to gain control, and we believe a key element is its alignment with IT.

Moreover, digital technologies enabled not only marketing tools but also completely new businesses such as online platforms, which provide services such as transactions, bookings and arrangements. Companies and start-ups have arisen that do not provide dedicated services or products for the customers themselves but refer them to other companies or individuals, examples of which are holiday booking platforms or any type of portal where customers can compare and buy services or products up to dating platforms. We have not considered these types of businesses because we have 
focused on marketing tools. However, those platforms play a significant role in the marketing of companies that actually provide the referred product or service.

The current COVID-19 pandemic is one example of why enabling technologies have gained importance for corporations. Many firms have begun outsourcing functions to data centers, and work from home has become an important instrument to keep the functions of corporations running (eWeek Editors 2020). Accordingly, customers' behaviors and responsiveness have changed unpredictably. In our study, we focused within the established eras on the timespan and sequencing, but there are clearly more variables such as culture, society and events, which have impacts on the importance of digital tools. Furthermore, those variables have also hindered the evolution of some tools. In this study, we have ignored such constraints for clarity.

\section{Managerial implications}

The findings of this study have a number of practical implications. First, continuously improved marketing tools are one essential key factor for customer acquisition and retention. However, enabling technologies and smart tools alone are not sufficient for a sustainable customer acquisition approach. Second, companies need new organizational designs and a common understanding of aligned and separated responsibilities, which could lead to new setups in working relationships (Edelman and Singer 2015; Matt et al. 2015; Bharadwaj et al. 2013). Third, marketing managers should carefully analyze their digital capabilities and innovativeness in addition to the applied digital marketing tools (Karjaluoto et al. 2014; Feng et al. 2020). Continued efforts are necessary to make data more accessible and match marketing managers' needs. Data and automation are two key levers of digital transformation, which will produce organizational benefits and facilitate customer interaction. 
Following the marketing evolution, it is not surprising that a gap between necessary knowledge and required knowledge in the digitalization of marketing tools exists. A key policy priority should therefore be to plan for the long-term care of digital tools in marketing. In return, another important practical implication is that IT managers should analyze the usability and purpose of enabling technologies. Both departments need to carefully consider the customer perspective when thinking about the right marketing tool and should even integrate the customer into the design process.

\section{Guidelines for future research}

This study has raised many questions in need of further investigation. The increasing amount of data concerning customers behavior and the personalization of products and services are barely part of the models so far. Researchers should reveal the advantages of new technologies that gather data and the increasing amount of provided data. However, the major driver for future research is the control of customer and marketing touchpoints. Researchers should consider the meaning of the touchpoints and compare those with the intended use (Schmitt 1999; Hassenzahl 2018). In addition, a guideline on what touchpoints are within marketing control and how marketing could gain control of more touchpoints should be a field of future research.

Additionally, another important aspect is to analyze to what extent marketing capabilities are able to respond to changing technologies (Day 2011). Marketing managers as users and designers of tools need knowledge about functionalities and require the coordination of such tools to assess whether the designed tools work (Henseler and Guerreiro 2020). They should acquire the required capabilities to use the tools efficiently (Dave Chaffey and Mark E Patron 2012). It will be essential to investigate what knowledge and talents are required and what knowledge gap between 
Information Technology and Marketing - An Important Partnership for Decades

IT and marketing is reasonable. Furthermore, researchers should aim to conclude these aspects regarding the degree to which marketing and IT should be aligned.

\section{Tables and figures}

Table 1. Enabling technologies, emerging marketing tools and the corresponding marketing domains

Figure 1. Eras in enabling technologies and emerging marketing tools

Figure 2. Digital transformation in marketing 
Table 1. Enabling technologies, emerging marketing tools and the corresponding marketing domains

\begin{tabular}{|c|c|c|c|c|c|c|}
\hline Enabling Technology & Year & Reference & Marketing tool & Year & Reference & $\begin{array}{l}\text { Marketing } \\
\text { domain }\end{array}$ \\
\hline \multirow[t]{2}{*}{ Telecommunications } & \multirow[t]{2}{*}{1961} & \multirow{2}{*}{ (Hopner 1961) } & Telecommunications shopping & 1983 & (George 2015) & \\
\hline & & & Telemarketing & 1993 & (Luke 2015) & \\
\hline \multirow{2}{*}{$\begin{array}{l}\text { Speech understanding } \\
\text { system }\end{array}$} & \multirow[t]{2}{*}{1996} & \multirow[t]{2}{*}{ (Kawahara et al. 1996) } & Access-automated call center & 1997 & (Ehrlich et al. 1997) & \\
\hline & & & $\begin{array}{l}\text { IT enabled call center (ICIS) } \\
\text { Call center (AMS) }\end{array}$ & $\begin{array}{l}2001 \\
2008\end{array}$ & $\begin{array}{l}\text { (Subramanyam and } \\
\text { Krishnan 2001), (Wang et } \\
\text { al. 2015) }\end{array}$ & \\
\hline \multirow{5}{*}{$\begin{array}{l}\text { Data Management } \\
\text { Systems } \\
\text { ERP }\end{array}$} & \multirow[t]{5}{*}{1987} & \multirow[t]{5}{*}{ (Sarda 1987) } & Sales control systems & 1994 & $\begin{array}{l}\text { (Bingham and Quigley } \\
\text { 2015) }\end{array}$ & \multirow{7}{*}{$\begin{array}{l}\text { (Customer) } \\
\text { Relationship } \\
\text { Marketing } \\
\text { "International } \\
\text { Journal of } \\
\text { Customer } \\
\text { Relationship } \\
\text { Marketing } \\
\text { and } \\
\text { Management" }\end{array}$} \\
\hline & & & Data base marketing & 1998 & (Chopoorian et al. 2015) & \\
\hline & & & E-CRM & 2001 & $\begin{array}{l}\text { (Galbreath and Hoffman } \\
\text { 2015) }\end{array}$ & \\
\hline & & & CRM & 2002 & (Kim et al. 2002) & \\
\hline & & & $\begin{array}{l}\text { B2B customer database } \\
\text { management }\end{array}$ & 2006 & (Zahay 2015) & \\
\hline \multirow[t]{2}{*}{ Cloud Infrastructures } & \multirow[t]{2}{*}{2009} & \multirow{2}{*}{$\begin{array}{l}\text { (Püschel and Neumann } \\
\text { 2009) }\end{array}$} & Mobile CRM & 2013 & (Töllinen et al. 2015) & \\
\hline & & & Mobile sales force automation & 2013 & (Karjaluoto et al. 2015) & \\
\hline \multirow{6}{*}{$\begin{array}{l}\text { Knowledge-based } \\
\text { Systems }\end{array}$} & \multirow[t]{2}{*}{1990} & \multirow[t]{2}{*}{ (Kumar 1990) } & Knowledge-based system pricing & 1993 & (Mentzer et al. 2015) & \multirow{6}{*}{$\begin{array}{l}\text { "Journal of } \\
\text { Relationship } \\
\text { Marketing" }\end{array}$} \\
\hline & & & Competitive intelligence systems & 1995 & (Cartwright et al. 2015) & \\
\hline & 1990 & (Schocken 1000) & Strategic intelligence systems & 1995 & (Festervand et al. 2015) & \\
\hline & & (scnоскеп 1990) & Web-based knowledge management & 2003 & (Liu and Luo 2015) & \\
\hline & & & IT in decision making & 2004 & (Rieger et al. 2015) & \\
\hline & & & Online dynamic pricing & 2006 & (Chung 2015) & \\
\hline \multirow[t]{3}{*}{ E-Mail } & \multirow[t]{3}{*}{1992} & \multirow{3}{*}{$\begin{array}{l}\text { (El-Shinnawy and Markus } \\
\text { 1992) }\end{array}$} & $\begin{array}{l}\text { E-Mail as a method of } \\
\text { communication }\end{array}$ & 1997 & (Heiser and Frontczak 2015) & \\
\hline & & & E-Mail survey & 1998 & (Flaherty et al. 2015) & \\
\hline & & & E-Mail-marketing & 2005 & (Ceyp 2015) & \\
\hline \multirow[t]{2}{*}{ Internet } & \multirow[t]{2}{*}{1993} & \multirow[t]{2}{*}{ (Kambil et al. 1993) } & Electronic commerce (ICIS) & 1995 & (Ives et al. 1995) & \multirow{2}{*}{$\begin{array}{l}\text { Online } \\
\text { Marketing } \\
2002\end{array}$} \\
\hline & & & Internet advertising (web-based) & 1997 & $\begin{array}{l}\text { (Löbbecke and Powell } \\
\text { 1997) }\end{array}$ & \\
\hline
\end{tabular}




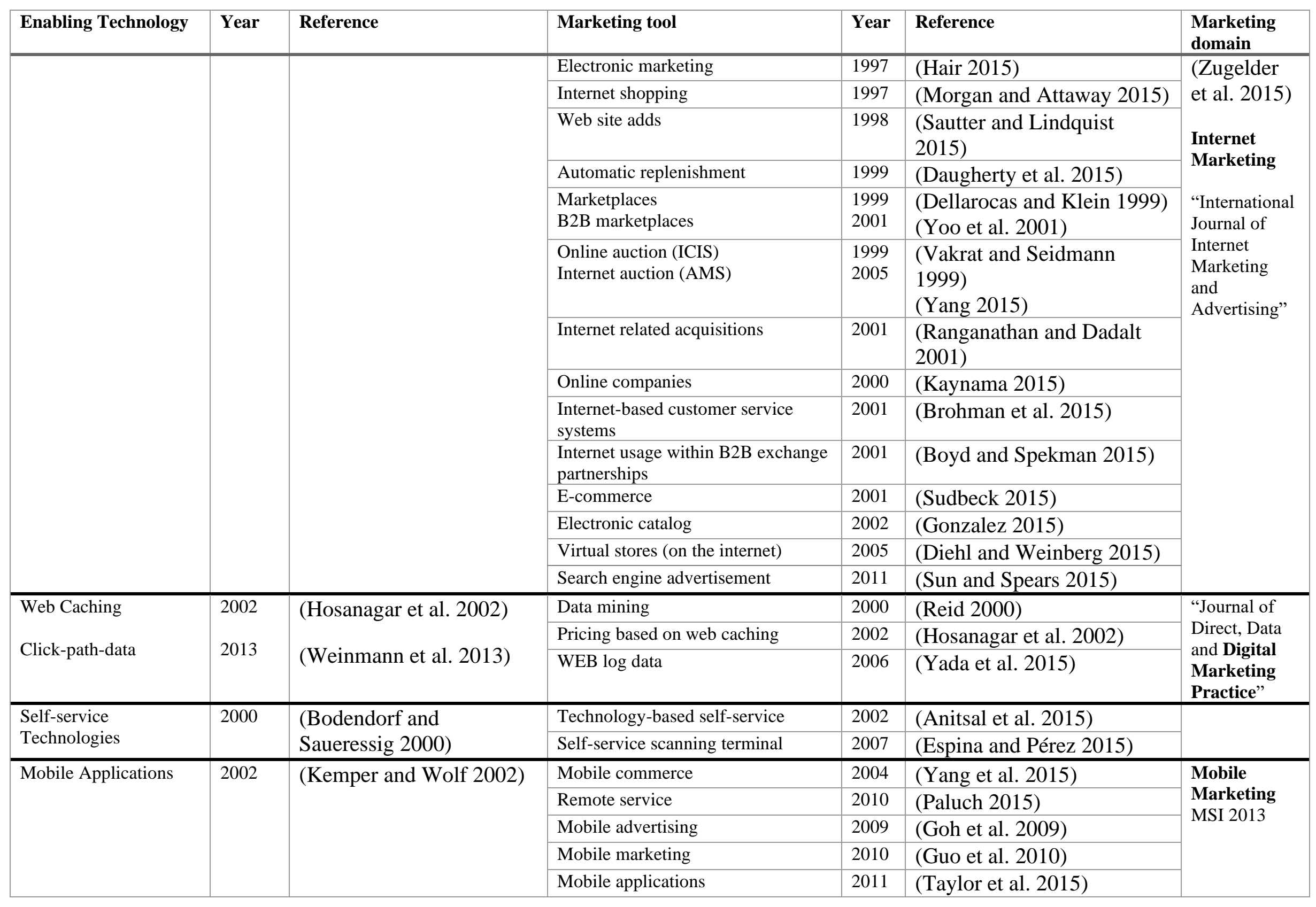




\begin{tabular}{|c|c|c|c|c|c|c|}
\hline Enabling Technology & Year & Reference & Marketing tool & Year & Reference & $\begin{array}{l}\text { Marketing } \\
\text { domain }\end{array}$ \\
\hline & & & Digital coupons (sms) & 2011 & (Nakhata 2015) & \\
\hline & & & $\begin{array}{l}\text { Freemium (ICIS) } \\
\text { Freemium (AMS) }\end{array}$ & $\begin{array}{l}2012 \\
2016\end{array}$ & $\begin{array}{l}\text { (Liu et al. 2012) } \\
\text { (Cziehso and Schaefers } \\
\text { 2017) }\end{array}$ & \\
\hline & & & Mobile shopping & 2013 & (Swilley and Cowart 2015) & \\
\hline & & & Mobile commerce on tablet & 2013 & (Han et al. 2013) & \\
\hline $\begin{array}{l}\text { Mobile Self-service } \\
\text { Technologies }\end{array}$ & 2006 & $\begin{array}{l}\text { (Treiblmaier and } \\
\text { Dickinger 2006) }\end{array}$ & Mobile banking & 2011 & (Nel et al. 2015) & \\
\hline \multirow{11}{*}{$\begin{array}{l}\text { User Generated Content } \\
\text { (UGC) }\end{array}$} & \multirow{11}{*}{$\begin{array}{l}2003 \\
\text { (ICME) } \\
2008 \\
\text { (ICIS) }\end{array}$} & \multirow{11}{*}{$\begin{array}{l}\text { (Koskinen 2003) } \\
\text { (Oh et al. 2008) }\end{array}$} & Online reviews & 2004 & (Dellarocas et al. 2004) & \multirow{14}{*}{$\begin{array}{l}\text { Online } \\
\text { Marketing } \\
2002 \\
\text { (Zugelder } \\
\text { et al. 2015) }\end{array}$} \\
\hline & & & Online community & 2006 & (Landry et al. 2015) & \\
\hline & & & Online product review & 2012 & $\begin{array}{l}\text { (Coussement and Antioco } \\
\text { 2015) }\end{array}$ & \\
\hline & & & Online product rating assessment & 2014 & (Wang et al. 2016) & \\
\hline & & & Online discussion forums & 2016 & (Murray and Maceli 2017) & \\
\hline & & & $\begin{array}{l}\text { Online recommendations and } \\
\text { feedback }\end{array}$ & 2004 & (Chen et al. 2004) & \\
\hline & & & $\begin{array}{l}\text { eWOM (AMS) } \\
\text { Electronic word of mouth (ICIS) }\end{array}$ & $\begin{array}{l}2000 \\
2010\end{array}$ & $\begin{array}{l}\text { (Bussière 2015) } \\
\text { (Lo and Lin 2010) }\end{array}$ & \\
\hline & & & Online user comments & 2011 & (Mills et al. 2015) & \\
\hline & & & Interactive websites & 2012 & (Liu 2015) & \\
\hline & & & Firm-generated content & 2014 & (Swain and Cao 2014) & \\
\hline & & & Reputation management & 2016 & (Chen et al. 2016) & \\
\hline \multirow[t]{3}{*}{$\mathrm{B} \log \mathrm{s}$} & \multirow[t]{3}{*}{2006} & \multirow[t]{3}{*}{ (Xu and Chau 2006) } & Blog users/Bloggers & 2012 & (Segev et al. 2015) & \\
\hline & & & Sponsored blog post & 2015 & $\begin{array}{l}\text { (Williams and Hodges } \\
\text { 2016) }\end{array}$ & \\
\hline & & & Vlogs & 2017 & $\begin{array}{l}\text { (Munnukka and Maity } \\
\text { 2018) }\end{array}$ & \\
\hline $\begin{array}{l}\text { Machine Learning } \\
\text { Dynamic Time } \\
\text { Warping }\end{array}$ & $\begin{array}{l}2008 \\
2014\end{array}$ & $\begin{array}{l}\text { (Ichise 2008) } \\
\text { (Keller et al. 2014) }\end{array}$ & Prediction of sales performance & 2011 & (Boso et al. 2015) & \multirow{3}{*}{$\begin{array}{l}\text { "Journal of } \\
\text { Direct, Data } \\
\text { and Digital } \\
\text { Marketing } \\
\text { Practice" }\end{array}$} \\
\hline \multirow[t]{2}{*}{ Artificial Intelligence } & \multirow[t]{2}{*}{2018} & \multirow[t]{2}{*}{ (Tremblay et al. 2018) } & Robotic shopping assistant & 2018 & (Fukawa and Huang 2018) & \\
\hline & & & Robo-advisor & 2018 & (Tremblay et al. 2018) & \\
\hline
\end{tabular}




\begin{tabular}{|c|c|c|c|c|c|c|}
\hline Enabling Technology & Year & Reference & Marketing tool & Year & Reference & $\begin{array}{l}\text { Marketing } \\
\text { domain }\end{array}$ \\
\hline & & & $\begin{array}{l}\text { Dynamic pricing based on artificial } \\
\text { intelligence }\end{array}$ & 2019 & (Beser et al. 2019) & \\
\hline & & & Artificial intelligence in marketing & 2018 & (Pitt et al. 2018) & \\
\hline Big Data & 2014 & (Hristova 2014) & Adaptive Big Data analytics & 2014 & (Zhang et al. 2014) & \\
\hline \multirow[t]{9}{*}{ Social Media } & \multirow[t]{9}{*}{2009} & \multirow[t]{9}{*}{ (Xu and Zhang 2009) } & Social media influencers & 2010 & (Lindsay et al. 2015) & \multirow{7}{*}{$\begin{array}{l}\text { Social Media } \\
\text { Marketing } \\
2012 \\
\text { (Bauer et } \\
\text { al. 2015) } \\
\text { "Journal of } \\
\text { Digital and } \\
\text { Social Media } \\
\text { Marketing" }\end{array}$} \\
\hline & & & Social networking & 2010 & (Ulusu et al. 2015) & \\
\hline & & & $\begin{array}{l}\text { Social media applications for } \\
\text { marketing }\end{array}$ & 2011 & (Tuten et al. 2015) & \\
\hline & & & Social media analytics & 2013 & (Kurniawati et al. 2013) & \\
\hline & & & $\begin{array}{l}\text { Enterprise social media } \\
\text { Corporate social media sides }\end{array}$ & $\begin{array}{l}2014 \\
2016\end{array}$ & $\begin{array}{l}\text { (Dyrby et al. 2014) } \\
\text { (Bacile et al. 2017) }\end{array}$ & \\
\hline & & & Managing social consumer voice & 2015 & $\begin{array}{l}\text { (Melancon and Dalakas } \\
\text { 2016) }\end{array}$ & \\
\hline & & & Purchase feature in social media & 2017 & (Guo et al. 2017) & \\
\hline & & & Influential tool & 2017 & (Gomez et al. 2018) & \multirow[b]{2}{*}{$\begin{array}{l}\text { Influencer } \\
\text { Marketing } \\
2019 \\
\text { (Wiedmann } \\
\text { and } \\
\text { Mettenheim } \\
2020 \text { ) }\end{array}$} \\
\hline & & & Influencer & 2016 & (Ferreira 2017) & \\
\hline \multirow[t]{2}{*}{ Wearable Technology } & \multirow[t]{2}{*}{2015} & \multirow{2}{*}{$\begin{array}{l}\text { (Deng and } \\
\text { Christodoulidou 2015) } \\
\text { (Robson et al. 2016) }\end{array}$} & Digital (consumer) self-tracking & 2015 & (Yuksel and Milne 2016) & \multirow{6}{*}{$\begin{array}{l}\text { Journal of } \\
\text { "Applied } \\
\text { Marketing } \\
\text { Analytics" }\end{array}$} \\
\hline & & & Trace data of user & 2017 & (Frank et al. 2017) & \\
\hline \multirow[t]{4}{*}{ Web Analytics } & \multirow[t]{4}{*}{2013} & \multirow[t]{4}{*}{ (Paramonov et al. 2013) } & Web analytics & 2012 & (Järvinen et al. 2015) & \\
\hline & & & Text content analysis & 2014 & (Hood 2016) & \\
\hline & & & Text analysis of online reviews & 2016 & (Fresneda and Gefen 2017) & \\
\hline & & & Personalized advertising & 2015 & $\begin{array}{l}\text { (Gironda and Korgaonkar } \\
\text { 2016) }\end{array}$ & \\
\hline Internet of Things & 2015 & $\begin{array}{l}\text { (Chmaj and Selvaraj } \\
\text { 2015) }\end{array}$ & $\begin{array}{l}\text { Internet of things (IoTs) and } \\
\text { marketing }\end{array}$ & 2018 & (Anwar 2018) & $\begin{array}{l}\text { "International } \\
\text { Journal of }\end{array}$ \\
\hline
\end{tabular}




\begin{tabular}{|c|c|c|c|c|c|c|}
\hline Enabling Technology & Year & Reference & Marketing tool & Year & Reference & $\begin{array}{l}\text { Marketing } \\
\text { domain }\end{array}$ \\
\hline \multirow{3}{*}{$\begin{array}{l}\text { Augmented Reality } \\
\text { Virtual Reality }\end{array}$} & \multirow{3}{*}{$\begin{array}{l}2007 \\
2017\end{array}$} & \multirow{3}{*}{$\begin{array}{l}\text { (Liu et al. 2007) } \\
\text { (Blazauskas et al. 2017) }\end{array}$} & Augmented reality with customers & 2016 & (Poushneh 2017) & \multirow{4}{*}{$\begin{array}{l}\text { Technology } \\
\text { Marketing" }\end{array}$} \\
\hline & & & 3D virtual shopping environments & 2013 & (Mann et al. 2015) & \\
\hline & & & B2B virtual trade shows & 2010 & (Gabisch 2015) & \\
\hline Blockchain & 2016 & (Avital et al. 2016) & Cryptocurrencies & 2018 & (Mauri et al. 2018) & \\
\hline \multirow[t]{5}{*}{ IT Enabled Cocreation } & \multirow[t]{5}{*}{2008} & \multirow[t]{5}{*}{ (Grace et al. 2008) } & Cocreation & 2007 & (Campbell et al. 2015) & \\
\hline & & & $\begin{array}{l}\text { Innovation processes on the internet } \\
\text { (cocreation) }\end{array}$ & 2009 & (Emrich and Rudolph 2015) & \\
\hline & & & Expanding cocreation & 2012 & (Kull 2015) & \\
\hline & & & $\begin{array}{l}\text { Cocreating with self-service } \\
\text { technology }\end{array}$ & 2012 & (Hughes et al. 2015) & \\
\hline & & & Crowdsourcing & 2012 & (Simula et al. 2015) & \\
\hline \multirow[t]{2}{*}{ Crowd Funding } & \multirow[t]{2}{*}{2013} & \multirow[t]{2}{*}{ (Zvilichovsky et al. 2013) } & Crowdfunding & 2014 & (Boeuf and Durivage 2016) & \\
\hline & & & $\begin{array}{l}\text { Customer participation in new } \\
\text { product development }\end{array}$ & 2015 & (Morgan and Obal 2016) & \\
\hline
\end{tabular}


Figure 1. Eras in enabling technologies and emerging marketing tools

\section{Antonomous IT Era}

Intelligent Networking Era

User-Enabled Mobile Era

Data-Managed Internet Marketing Era

Telecommunication Era

\begin{tabular}{|l|l|l|l|l|l|l|l|l|l|l|l|}
\hline 1980 & 1985 & 1990 & 1995 & 2000 & 2005 & 2010 & 2015 & 2020 & 2025 & 2030 & 2035 \\
\hline
\end{tabular}


Figure 2. Digital transformation in marketing

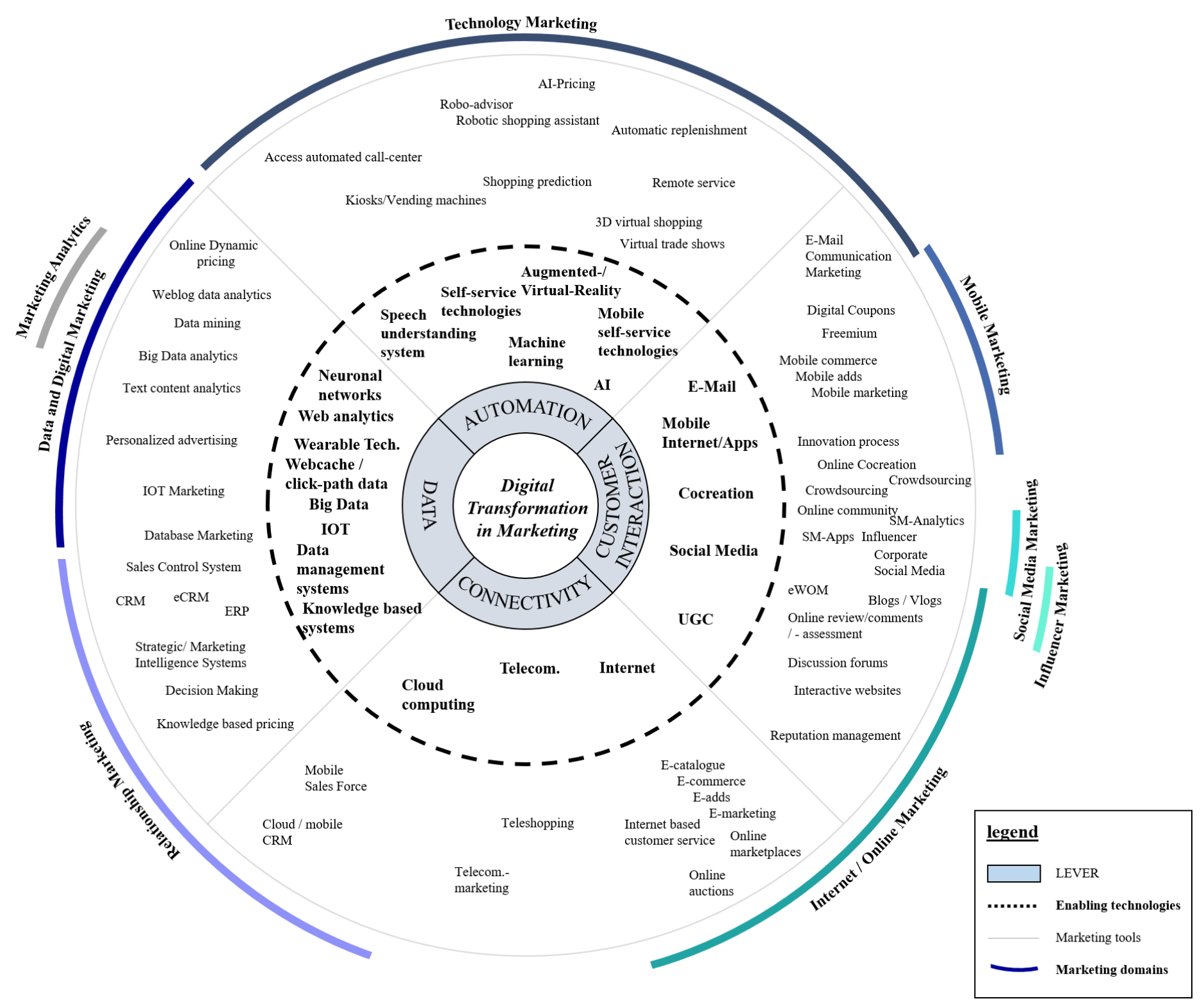




\section{References}

Agrawal, Ajay; Gans, Joshua; Goldfarb, Avi (2020): how to win with machine learning. In Harvard business review 98 (5), pp. 126-133.

AIS (2020a): Association for Information Systems ICIS Conferences. Available online at https://aisnet.org/page/ICISPage, checked on 7/20/2020.

AIS (2020b): International Conference on Information Systems (ICIS). Available online at https://aisel.aisnet.org/icis/, checked on 7/22/2020.

AMA (2020): Types of Marketing. Available online at https://www.ama.org/the-definition-ofmarketing-what-is-marketing/, checked on 7/22/2020.

AMS (2020): Academy of Marketing Science Annual Conference. Available online at https://www.ams-web.org/page/AboutConferences, checked on 7/21/2020.

Anitsal, Ismet; Moon, Mark A.; Anitsal, M. Meral (2015): Technology-Based Self-Service: Issues For Retail Management And Research. In Harlan E. Spotts (Ed.): Proceedings of the 2002 Academy of Marketing Science (AMS) Annual Conference. Cham, 2015. Cham: Springer International Publishing, pp. 25-36.

Anwar, Syed Tariq (2018): Internet of Things (IoTs) and Marketing: Conceptual Issues, Applications, and a Survey: An Abstract. In Nina Krey, Patricia Rossi (Eds.): Boundary Blurred: A Seamless Customer Experience in Virtual and Real Spaces. Cham, 2018. Cham: Springer International Publishing, p. 323.

Asatiani, Aleksandre; Penttinen, Esko; Rinta-Kahila, Tapani; Salovaara, Antti (2019):

Organizational Implementation of Intelligent Automation as Distributed Cognition: Six Recommendations for Managers. In : Proceedings of the $40^{\text {th }}$ International Conference on Information Systems, ICIS 2019, Munich, Germany, December 15-18, 2019.

Avital, Michel; Beck, Roman; King, John Leslie; Rossi, Matti; Teigland, Robin (2016): Jumping on the Blockchain Bandwagon: Lessons of the Past and Outlook to the Future. In : Proceedings of the International Conference on Information Systems - Digital Innovation at the Crossroads, ICIS 2016, Dublin, Ireland, December 11-14, 2016.

Bacile, Todd J.; Fox, Alexa K.; Wolter, Jeremy S.; Massa, Felipe (2017): Structured Abstract: All Online Complaints Are Not Created Equal, Corporate Social Media Pages as Customer Service Channels. In Maximilian Stieler (Ed.): Creating Marketing Magic and Innovative Future Marketing Trends. Cham, 2017. Cham: Springer International Publishing, pp. 23-28.

Baker, Walter; Kiewell; Winkler (2014): Using big data to make better pricing decisions. Edited by Mc Kinsey \& Company. Available online at https://www.mckinsey.com/business- 
functions/marketing-and-sales/our-insights/using-big-data-to-make-better-pricingdecisions, updated on 7/1/2014, checked on 7/25/2020.

Bauer, Hans H.; Toma, Boris; Fischer, Dirk (2015): Social Media Marketing on Facebook: Investigating Determinants and Consequences of Users' Attitude Toward the Facebook Page. In Robinson, Jr., Leroy (Ed.): Marketing Dynamism \& Sustainability: Things Change, Things Stay the Same... Cham, 2015. Cham: Springer International Publishing, p. 426.

Belanche, Daniel; Casaló, Luis V.; Flavián, Carlos (2019): Artificial Intelligence in FinTech: understanding robo-advisors adoption among customers. In Industr Mngmnt \& Data Systems 119 (7), pp. 1411-1430. DOI: 10.1108/IMDS-08-2018-0368.

Benitez, Jose; Ray, Gautam; Henseler, Jörg (2018): Impact of information technology infrastructure flexibility on mergers and acquisitions. In Management information systems : mis quarterly 42 (1), pp. 25-43.

Berger, Roland (2015): The digital transformation of industry. In The study commissioned by the Federation of German Industries (BDI), Munich (www. rolandberger. com/publications/publication_pdf/roland_berger_digital_transformation_of _industry_20150315.pdf).

Beser, Alper; Lackes, Richard; Siepermann, Markus (2019): Different Prices for Different Customers - Optimising Individualised Prices in Online Stores by Artificial Intelligence. In : Proceedings of the $40^{\text {th }}$ International Conference on Information Systems, ICIS 2019, Munich, Germany, December 15-18, 2019.

Bharadwaj, Anandhi; El Sawy, Omar A.; Pavlou, Paul A.; Venkatraman, N. (2013): Digital business strategy: toward a next generation of insights. In MIS Quarterly, pp. 471-482.

Bingham, Frank G.; Quigley, Charles J. (2015): Sales Control Systems: An Exploratory Study. In Elizabeth J. Wilson, William C. Black (Eds.): Proceedings of the 1994 Academy of Marketing Science (AMS) Annual Conference. Cham, 2015. Cham: Springer International Publishing, pp. 442-445.

Blazauskas, Tomas; Maskeliunas, Rytis; Bartkute, Reda; Kersiene, Vitalija; Jurkeviciute, Indre; Dubosas, Mindaugas (2017): Virtual Reality in Education: New Ways to Learn. In : Information and Software Technologies - $23^{\text {rd }}$ International Conference, ICIST 2017, Druskininkai, Lithuania, October 12-14, 2017, Proceedings, pp. 457-465.

Bodendorf, Freimut; Saueressig, Gabriele (2000): Internet Based Self Service Systems for Customer-Oriented Processes in Public Administration. In : Proceedings of the $8^{\text {th }}$ European Conference on Information Systems, Trends in Information and Communication Systems for the $21^{\text {st }}$ Century, ECIS 2000, Vienna, Austria, July 3-5, 2000, pp. 1131-1135. 
Boeuf, Benjamin; Durivage, François (2016): Make Them Pay! Understanding Consumer Participation in Crowdfunding. In Michael W. Obal, Nina Krey, Christian Bushardt (Eds.): Let's Get Engaged! Crossing the Threshold of Marketing's Engagement Era. Cham, 2016. Cham: Springer International Publishing, pp. 95-96.

Borch, Fred J. (1957): The marketing philosophy as a way of business life. In The marketing concept: Its meaning to management, pp. 3-16.

Bornstein, Julie; McGinn, Dan (2014): How Sephora Reorganized to Become a More Digital Brand: Harvard Business School Publication Corp. In Harvard Business Review Digital Articles.

Boso, Nathaniel; Cadogan, John W.; Story, Vicky M. (2015): Do Coordination Flexibility and Market Orientation Leverage Entrepreneurial Strategy to Predict Export Sales Performance? In Mary Conway Dato-on (Ed.): The Sustainable Global Marketplace. Cham, 2015. Cham: Springer International Publishing, p. 125.

Bowler, Caitlin N.; Datar, Srikant M. (2017): Data Science at Target. In Harvard Business School Cases.

Boyd, D. Eric; Spekman, Robert E. (2015): Internet Usage within B2B Exchange Partnerships: A Concecptual Model and Research Propositions. In Melissa Moore, Robert S. Moore (Eds.): New Meanings for Marketing in a New Millennium. Cham, 2015. Cham: Springer International Publishing, p. 258.

Brohman, Kathryn; Parasuraman, A.; Watson, Richard T.; Piccoli, Gabriele (2015): InternetBased Customer Service Systems: What are They and When are They Successful?1. In Melissa Moore, Robert S. Moore (Eds.): New Meanings for Marketing in a New Millennium. Cham, 2015. Cham: Springer International Publishing, pp. 150-153. Bussière, Dave (2015): Evidence and Implications of Electronic Word of Mouth. In Harlan E. Spotts, H. Lee Meadow (Eds.): Proceedings of the 2000 Academy of Marketing Science (AMS) Annual Conference. Cham, 2015. Cham: Springer International Publishing, p. 361.

Byrum, Joseph (2019): Engineering the intelligent enterprise: Augmented intelligence can't match human thinking but can optimize business processes. In ISE: Industrial \& Systems Engineering at Work 51 (1), pp. 40-43.

Campbell, Colin; Pitt, Leyland F.; Berthon, Pierre (2015): Multiple Meanings? A Mutual Knowledge Perspective on Brand Co-creation. In Dheeraj Sharma, Shaheen Borna (Eds.): Proceedings of the 2007 Academy of Marketing Science (AMS) Annual Conference. Cham, 2015. Cham: Springer International Publishing, p. 260.

Cartwright, Donna L.; Boughton, Paul D.; Miller, Stephen W. (2015): The Perceived Usefulness of Competitive Intelligence Systems and Relationship to the Strategic Orientation of the Firm. In Roger Gomes (Ed.): Proceedings of the 1995 Academy of Marketing Science 
(AMS) Annual Conference. Cham, 2015. Cham: Springer International Publishing, p. 107.

Ceyp, Michael H. (2015): Development Prospects in E-Mail-Marketing - Conception and Latest Empirical Findings. In Harlan E. Spotts (Ed.): Marketing, Technology and Customer Commitment in the New Economy. Cham, 2015. Cham: Springer International Publishing, pp. 179-183.

Chaffey, Dave; Smith, Paul Russell (2013): eMarketing eXcellence: Planning and optimizing your digital marketing: Routledge.

Chang, Shuchih Ernest; Chen, Yi-Chian; Wu, Tzu-Ching (2019): Exploring blockchain technology in international trade: Business process re-engineering for letter of credit. In Industr Mngmnt \& Data Systems 119 (8), pp. 1712-1733. DOI: 10.1108/IMDS-122018-0568.

Chaudhuri, Atanu; Rogers, Helen; Soberg, Peder; Pawar, Kulwant S. (2019): The role of service providers in 3D printing adoption. In Industr Mngmnt \& Data Systems 119 (6), pp. 1189-1205. DOI: 10.1108/IMDS-08-2018-0339.

Chen, Pei-Yu Sharon; Wu, Shin-yi; Yoon, Jungsun (2004): The Impact of Online Recommendations and Consumer Feedback on Sales. In : Proceedings of the International Conference on Information Systems, ICIS 2004, December 12-15, 2004, Washington, DC, USA, pp. 711-724.

Chen, Yanzhen; Rui, Huaxia; Whinston, Andrew B. (2016): Does Reputation Management on Social Media Boost Career? Evidence from the Market for Executives. In : Proceedings of the International Conference on Information Systems - Digital Innovation at the Crossroads, ICIS 2016, Dublin, Ireland, December 11-14, 2016.

Chmaj, Grzegorz; Selvaraj, Henry (2015): Energy-efficient distributed computing solutions for Internet of Things with ZigBee devices. In : $14^{\text {th }}$ IEEE/ACIS International Conference on Computer and Information Science, ICIS 2015, Las Vegas, NV, USA, June 28 - July 1, 2015, pp. 437-442.

Chopoorian, John A.; Khalil, Omar E. M.; Ahmed, Mehnaz (2015): Data Quality and Database Marketing. In John B. Ford, Honeycutt, Jr., Earl D (Eds.): Proceedings of the 1998 Academy of Marketing Science (AMS) Annual Conference. Cham, 2015. Cham: Springer International Publishing, pp. 248-253.

Chung, Christina (2015): Online Communication Trust and Cultural Variables: The Comparison of American and Japanese Online Consumer Trust in Dynamic Pricing. In Harlan E. Spotts (Ed.): Revolution in Marketing: Market Driving Changes. Cham, 2015. Cham: Springer International Publishing, pp. 236-240.

Coltman, Tim; Tallon, Paul; Sharma, Rajeev; Queiroz, Magno (2015): Strategic IT alignment: twenty-five years on. In J Inf Technol 30 (2), pp. 91-100. DOI: 10.1057/jit.2014.35. 
Costa, W. G. (1996): An Australian Call Center Answers The Need for Novell [R] Support. In TELEMARKETING 14, pp. 88-91.

Coussement, Kristof; Antioco, Michael (2015): Managing Information Overload: The Case of Online Product Review Categorization. In Robinson, Jr., Leroy (Ed.): Marketing Dynamism \& Sustainability: Things Change, Things Stay the Same... Cham, 2015. Cham: Springer International Publishing, p. 548.

Cziehso, Gerrit Paul; Schaefers, Tobias (2017): To Be Continued...The Effects of Interrupted Preview Endings on Purchase Decisions in "Freemium" Business Models: An Abstract. In Maximilian Stieler (Ed.): Creating Marketing Magic and Innovative Future Marketing Trends. Cham, 2017. Cham: Springer International Publishing, pp. 517-518. Daugherty, Patricia J.; Ellinger, Alexander E.; Myers, Matthew B. (2015): Automatic Replenishment Programs: Forging Supply Chain Relationships. In Charles H. Noble (Ed.): Proceedings of the 1999 Academy of Marketing Science (AMS) Annual Conference. Cham, 2015. Cham: Springer International Publishing, p. 219.

Dave Chaffey; Mark E Patron (2012): From web analytics to digital marketing optimization: Increasing the commercial value of digital analytics. In Journal of Direct, Data and Digital Marketing Practice 14, pp. 30-45.

Day, George S. (2011): Closing the Marketing Capabilities Gap. In Journal of Marketing 75 (4), pp. 183-195. DOI: 10.1509/jmkg.75.4.183.

Dellarocas, Chrysanthos; Awad, Neveen Farag; Zhang, Xiaoquan (2004): Exploring the Value of Online Reviews to Organizations: Implications for Revenue Forecasting and Planning. In : Proceedings of the International Conference on Information Systems, ICIS 2004, December 12-15, 2004, Washington, DC, USA, pp. 379-386.

Dellarocas, Chrysanthos; Klein, Mark (1999): Designing robust, open electronic marketplaces of contract net agents. In : Proceedings of the Twentieth International Conference on Information Systems, ICIS 1999, Charlotte, North Carolina, USA, December 13-15, 1999, pp. 495-500.

Deng, Xuefei; Christodoulidou, Natasa (2015): Understanding User Values of Wearable Computing. In : Proceedings of the International Conference on Information Systems Exploring the Information Frontier, ICIS 2015, Fort Worth, Texas, USA, December 1316, 2015.

Dewsnap, B.; Jobber, David (2000): The Sales-Marketing Interface in Consumer PackagedGoods Companies: A Conceptual Framework. In Journal of Personal Selling \& Sales Management Spring 2000 (2), pp. 109-119. DOI: 10.1080/08853134.2000.10754230.

Dholakia, Nikhilesh; Zwick, Detlev; Denegri-Knott, Janice (2011): Technology, Consumers, and Marketing Theory. In : The SAGE Handbook of Marketing Theory. 1 Oliver's 
Yard, 55 City Road, London EC1Y 1SP United Kingdom: SAGE Publications Ltd, pp. 494-512.

Diehl, Sandra; Weinberg, Peter (2015): A Behavioral Model for Both Real Stores and Virtual

Stores on the Internet. In Harlan E. Spotts (Ed.): Marketing, Technology and Customer Commitment in the New Economy. Cham, 2015. Cham: Springer International Publishing, pp. 69-76.

Domínguez-Escrig, Emilio; Broch, Francisco Fermín Mallén; Lapiedra, Rafael; Chiva, Ricardo (2018): Promoting radical innovation through end-user computing satisfaction. In Industr Mngmnt \& Data Systems 118 (8), pp. 1629-1646. DOI: 10.1108/IMDS-062017-0256.

Dowd, Jessie (2019): Retail's Robotic Revolution. In Design: Retail 31 (5), p. 6.

Drnevich, Paul L.; Croson, David C. (2013): Information Technology and Business-Level Strategy: Toward an Integrated Theoretical Perspective. In MIS Quarterly 37 (2), pp. 483-509.

Dyrby, Signe; Jensen, Tina; Avital, Michel (2014): Enterprise Social Media at Work: Weaving the Social Fabric of Collaboration. In : Proceedings of the International Conference on Information Systems - Building a Better World through Information Systems, ICIS 2014, Auckland, New Zealand, December 14-17, 2014.

Edelman, David C.; Singer, Marc (2015): Competing on customer journeys. In Harvard business review 93 (11), pp. 88-100.

Ehrlich, Ute; Hanrieder, Gerhard; Hitzenberger, Ludwig; Heisterkamp, Paul; Mecklenburg, Klaus; Regel-Brietzmann, Peter (1997): Access - automated call center through speech understanding system. In : Fifth European Conference on Speech Communication and Technology, EUROSPEECH 1997, Rhodes, Greece, September 22-25, 1997.

Elsevier (2020): Scopus. Available online at https://www.elsevier.com/_data/assets/excel_doc/0015/91122/Sourcetitles_ext_list_June_2020.xlsx, checked on 7/22/2020.

El-Shinnawy, Maha M.; Markus, M. Lynne (1992): Media Richness Theory and New Electronic Communication Media: A Study of Voice Mail and Electronic Mail. In : Proceedings of the Thirteenth International Conference on Information Systems, Dallas, Texas, USA, December 13-16, 1992, pp. 91-105.

Emrich, Oliver; Rudolph, Thomas (2015): Linking Service and Innovation Processes on the Internet: A Framework for Customer-Firm Constellations in Electronic Networks. In Robinson, Jr., Leroy (Ed.): Proceedings of the 2009 Academy of Marketing Science (AMS) Annual Conference. Cham, 2015. Cham: Springer International Publishing, p. 104. 
Espina, Carmen; Pérez, Myra (2015): The Effect of Self-Scanning on Consumers' Expectations and Satisfaction: An Exploratory Study In A Retail Service Setting. In Dheeraj Sharma, Shaheen Borna (Eds.): Proceedings of the 2007 Academy of Marketing Science (AMS) Annual Conference. Cham, 2015. Cham: Springer International Publishing, pp. 308313.

eWeek Editors (2020): Why Remote Hands is Becoming a Trend in IT Systems. In eWeek, N.PAG-N.PAG.

Feng, Chao; Xi Nannan; Zhuang, Guijun; Hamari, Juho (2020): The role of interactive practice in business performance. In Industr Mngmnt \& Data Systems 120 (8), pp. 1521-1542. DOI: 10.1108/IMDS-01-2020-0042.

Fernandez, Carlos; Provost, Foster J.; Han, Xintian (2019): Counterfactual Explanations for Data-Driven Decisions. In : Proceedings of the $40^{\text {th }}$ International Conference on Information Systems, ICIS 2019, Munich, Germany, December 15-18, 2019.

Ferreira, Daniela Abrantes (2017): Structured Abstract: Instagram Influencers and the Illusion of a Perfect Body-An Analysis Based on Bourdieu's Theoretical Contribution. In Maximilian Stieler (Ed.): Creating Marketing Magic and Innovative Future Marketing Trends. Cham, 2017. Cham: Springer International Publishing, pp. 1147-1151.

Festervand, Troy A.; Lumpkin, James R.; Skelly, Gerald U. (2015): Strategic Intelligence Systems and the Salesforce. In Roger Gomes (Ed.): Proceedings of the 1995 Academy of Marketing Science (AMS) Annual Conference. Cham, 2015. Cham: Springer International Publishing, p. 155.

Flaherty, Theresa B.; Honeycutt, Earl D.; Powers, Deborah (2015): Exploring Text-Based Electronic Mail Surveys as a Means of Primary Data Collection. In John B. Ford, Honeycutt, Jr., Earl D (Eds.): Proceedings of the 1998 Academy of Marketing Science (AMS) Annual Conference. Cham, 2015. Cham: Springer International Publishing, pp. 260-264.

Fleischer, Joe (2004): Turn Support Into A Profit Center. In Call Center Magazine 17 (8), pp. $28-35$.

Frank, Leonhard; Gimpel, Henner; Schmidt, Marco; Schoch, Manfred (2017): Emergent User Roles of a Digital Workplace: A Network Analysis Based on Trace Data. In : Proceedings of the International Conference on Information Systems - Transforming Society with Digital Innovation, ICIS 2017, Seoul, South Korea, December 10-13, 2017.

Fresneda, Jorge; Gefen, David (2017): Applying Text Analysis to Determine Factors That Increase the Assessed Usefulness of Online Product Reviews: An Abstract. In Maximilian Stieler (Ed.): Creating Marketing Magic and Innovative Future Marketing Trends. Cham, 2017. Cham: Springer International Publishing, pp. 1405-1406. 
Fukawa, Nobuyuki; Huang, Yu-Shan (2018): Consumers' Willingness to Try a Robotic Shopping Assistant: The Role of Imagery: An Abstract. In Nina Krey, Patricia Rossi (Eds.): Boundary Blurred: A Seamless Customer Experience in Virtual and Real Spaces. Cham, 2018. Cham: Springer International Publishing, p. 89.

Furr, Nathan; Dyer, Jeff (2020): Lessons from Tesla's Approach to Innovation. In Harvard Business Review Digital Articles, pp. 1-5.

Gabisch, Jason (2015): The Role of B2B Virtual Trade Shows and Their Effect on Show Performance. In Dawn R. Deeter-Schmelz (Ed.): Proceedings of the 2010 Academy of Marketing Science (AMS) Annual Conference. Cham, 2015. Cham: Springer International Publishing, p. 339.

Galbreath, Jeremy; Hoffman, K. Douglas (2015): An Introduction to E-Services: The ABCs of an E-CRM Ecosystem. In Melissa Moore, Robert S. Moore (Eds.): New Meanings for Marketing in a New Millennium. Cham, 2015. Cham: Springer International Publishing, p. 242.

Gallaugher, John; Ransbotham, Sam (2010): SOCIAL MEDIA AND CUSTOMER DIALOG MANAGEMENT AT STARBUCKS. In MIS Quarterly Executive 9 (4).

Garmulewicz, Alysia; Holweg, Matthias; Veldhuis, Hans; Yang, Aidong (2018): Disruptive Technology as an Enabler of the Circular Economy: What Potential Does 3D Printing Hold? In California Management Review 60 (3), pp. 112-132. DOI:

10.1177/0008125617752695.

Gavett, Gretchen (2015): How Self-Service Kiosks Are Changing Customer Behavior: Harvard Business School Publication Corp. In Harvard Business Review Digital Articles.

Geng, Ruibin; Wang, Shichao; Chen, Xi; Song, Danyang; Yu Jie (2020): Content marketing in e-commerce platforms in the internet celebrity economy. In Industr Mngmnt \& Data Systems 120 (3), pp. 464-485. DOI: 10.1108/IMDS-05-2019-0270.

George, Richard J. (2015): The Future of Telecommunications Shopping: What are Cousumers Waiting for? In John C. Rogers III, Lamb, Jr., Charles W (Eds.): Proceedings of the 1983 Academy of Marketing Science (AMS) Annual Conference. Cham, 2015. Cham: Springer International Publishing, pp. 143-146.

Gerow, Jennifer E.; Thatcher, Jason Bennett; Grover, Varun (2014): Six types of IT-business strategic alignment: an investigation of the constructs and their measurement. In European Journal of Information Systems 24 (5), pp. 465-491. DOI: 10.1057/ejis.2014.6.

Gironda, John T.; Korgaonkar, Pradeep K. (2016): Personalized Advertising, Invasiveness, and Consumers' Attitudes: A Structured Abstract. In Kacy K. Kim (Ed.): Celebrating America's Pastimes: Baseball, Hot Dogs, Apple Pie and Marketing? Cham, 2016. Cham: Springer International Publishing, pp. 165-169. 
Gitlow, Howard S.; Wheatley, Edward W. (Eds.) (2016): Proceedings of the 1979 Academy of Marketing Science (AMS) Annual Conference. Cham, 2016. Cham: Springer International Publishing.

Goh, Khim-Yong; Chu, Hunhong; Soh, Winnie (2009): Mobile Advertising: An Empirical Study of Advertising Response and Search Behavior. In : Proceedings of the International Conference on Information Systems, ICIS 2009, Phoenix, Arizona, USA, December 15-18, 2009, p. 150.

Gomez, Lina; Bernabe, Kasim; Alvarado, Yanitzary; Meléndez, Lourdes (2018): Snapchat as an Influential Tool for Marketing Communication: An Exploratory Analysis of Brands Usage: An Abstract. In Nina Krey, Patricia Rossi (Eds.): Back to the Future: Using Marketing Basics to Provide Customer Value. Cham, 2018. Cham: Springer International Publishing, pp. 365-366.

Gonzalez, Christine (2015): Satisfaction Following an Electronic Catalogue Visit: The Impact of Perceived Legibility and Perceived Stimulation. In Harlan E. Spotts (Ed.): Proceedings of the 2002 Academy of Marketing Science (AMS) Annual Conference. Cham, 2015. Cham: Springer International Publishing, p. 172.

Grace, Audrey; Finnegan, Pat; Butler, Tom (2008): Service Co-Creation with the Customer: the Role of Information Systems. In : $16^{\text {th }}$ European Conference on Information Systems, ECIS 2008, Galway, Ireland, 2008, pp. 1656-1667.

Guo, Chenhui; Zhang, Bin; Chen, Xi; Góes, Paulo Barcelos (2017): Pay Easy, Buy More: An Empirical Study of the Purchase Feature in Social Media Apps. In : Proceedings of the International Conference on Information Systems - Transforming Society with Digital Innovation, ICIS 2017, Seoul, South Korea, December 10-13, 2017.

Guo, Xunhua; Zhao, Yannan; Jin, Yan; Zhang, Nan (2010): Theorizing a Two-Sided Adoption

Model for Mobile Marketing Platforms. In : Proceedings of the International Conference on Information Systems, ICIS 2010, Saint Louis, Missouri, USA, December 12-15, 2010, p. 128.

Guo, Yutong; Yong-Goh, Khim; Sayed, Mona Ragab (2019): Mobile Live Streaming: The Roles of Broadcasters' Screen Presence and Dynamic Emotions in Viewership Engagement. In : Proceedings of the $40^{\text {th }}$ International Conference on Information Systems, ICIS 2019, Munich, Germany, December 15-18, 2019.

Gupta, Sunil (2013): For Mobile Devices, Think Apps, Not Ads. (cover story). In Harvard business review 91 (3), pp. 70-75.

Hair, Joe F. (2015): The Impact of Technology on Marketing. In Elizabeth J. Wilson, Hair, Jr., Joseph F (Eds.): Proceedings of the 1997 Academy of Marketing Science (AMS) Annual Conference. Cham, 2015. Cham: Springer International Publishing, pp. 245246. 
Han, Sang Pil; Ghose, Anindya; Xu, Kaiquan (2013): Mobile Commerce in the New Tablet Economy. In : Proceedings of the International Conference on Information Systems, ICIS 2013, Milano, Italy, December 15-18, 2013.

Hansen, Rasmus Bech (2015): How Tesla, Under Armour, and Sonos Do Branding. In Harvard Business Review Digital Articles, pp. 2-4.

Hassenzahl, Marc (2018): The thing and I: understanding the relationship between user and product. In : Funology 2: Springer, pp. 301-313.

Heiser, Robert S.; Frontczak, Nancy T. (2015): The use and Effectiveness of E-Mail as a Method of Communication in Marketing Education. In Elizabeth J. Wilson, Hair, Jr., Joseph F (Eds.): Proceedings of the 1997 Academy of Marketing Science (AMS) Annual Conference. Cham, 2015. Cham: Springer International Publishing, pp. 104108.

Hennes \& Mauritz AB (2020): MarketLine Company Profile: H \& M Hennes \& Mauritz AB. In $H \&$ M Hennes \& Mauritz AB MarketLine Company Profile, pp. 1-45.

Henseler, Jörg; Guerreiro, Manuela (2020): Design and Marketing: Intersections and Challenges. In Creativity and Innovation Management (29 (5)).

Homburg, Christian; Vomberg, Arnd; Enke, Margit; Grimm, Philipp H. (2015): The loss of the marketing department's influence: is it really happening? And why worry? In $J$. of the Acad. Mark. Sci. 43 (1), pp. 1-13. DOI: 10.1007/s11747-014-0416-3.

Hood, Karen M. (2016): A Content Analysis of Texting and Driving Danger Advertisements. In Michael W. Obal, Nina Krey, Christian Bushardt (Eds.): Let's Get Engaged! Crossing the Threshold of Marketing's Engagement Era. Cham, 2016. Cham: Springer International Publishing, pp. 823-824.

Hopner, Emil (1961): Phase Reversal Data Transmission System for Switched and Private Telephone Line Applications. In IBM J. Res. Dev. 5 (2), pp. 93-105. DOI: 10.1147/rd.52.0093.

Horovitz, Bruce (2018): KIOSKS IN A SMARTPHONE AGE. In Restaurant Business 117 (3), p. 20.

Hosanagar, Kartik; Krishnan, Ramayya; Chuang, John; Choudhary, Vidyanand (2002): Optimal Pricing and Capacity Allocation in Vertically Differentiated Web Caching Services. In : Proceedings of the International Conference on Information Systems, ICIS 2002, Barcelona, Spain, December 15-18, 2002, p. 44.

Hristova, Diana (2014): Considering Currency in Decision Trees in the Context of Big Data. In : Proceedings of the International Conference on Information Systems - Building a Better World through Information Systems, ICIS 2014, Auckland, New Zealand, December 14-17, 2014. 
Hughes, Tim; Little, Ed; Hilton, Toni; Marandi, Ebi (2015): Co-Creating Value With SelfService Technology: Helping Customers Help Themselves. In Robinson, Jr., Leroy (Ed.): Marketing Dynamism \& Sustainability: Things Change, Things Stay the Same... Cham, 2015. Cham: Springer International Publishing, pp. 176-178.

Ianenko, Marina; Ianenko, Mikhail; Huhlaev, Dmitriy; Martynenko, Oksana (2019): Digital transformation of trade: problems and prospects of marketing activities. In IOP Conf. Ser.: Mater. Sci. Eng. 497, p. 12118. DOI: 10.1088/1757-899X/497/1/012118.

Iansiti, Marco; Lakhani, Karim R. (2020): COMPETING in THE AGE of AI. In Harvard business review 98 (1), pp. 60-67.

Ichise, Ryutaro (2008): Machine Learning Approach for Ontology Mapping Using Multiple Concept Similarity Measures. In : $7^{\text {th }}$ IEEE/ACIS International Conference on Computer and Information Science, IEEE/ACIS ICIS 2008, 14-16 May 2008, Portland, Oregon, USA, pp. 340-346.

Ignatius, A.D.I. (2017): “WE NEED PEOPLE TO LEAN INTO THE FUTURE”. In Harvard business review 95 (2), pp. 94-100.

Ives, Blake; Widmeyer, George R.; Parks, Michael S. (1995): The Electronic Commerce Course: An Early Vision of Learning in a Networked World. In : Proceedings of the Sixteenth International Conference on Information Systems, Amsterdam, The Netherlands, December 10-13, 1995, pp. 385-386.

Järvinen, Joel; Karjaluoto, Heikki (2015): The use of Web analytics for digital marketing performance measurement. In Industrial Marketing Management 50, pp. 117-127. DOI: 10.1016/j.indmarman.2015.04.009.

Järvinen, Joel; Töllmen, Aarne; Karjaluoto, Heiki (2015): Web Analytics and Social Media Monitoring in Industrial Marketing: Tools for Improving Marketing Communication Measurement. In Robinson, Jr., Leroy (Ed.): Marketing Dynamism \& Sustainability: Things Change, Things Stay the Same... Cham, 2015. Cham: Springer International Publishing, pp. 477-486.

Kambil, Ajit; Kahin, Brian; Kahle, Brewster (1993): Internet and Beyond: Building Public Data Infrastructures. In : Proceedings of the Fourteenth International Conference on Information Systems, Orlando, Florida, USA, December 5-8, 1993, p. 416.

Kaplan, Andreas M.; Haenlein, Michael (2010): Users of the world, unite! The challenges and opportunities of Social Media. In Business Horizons 53 (1), pp. 59-68. DOI: 10.1016/j.bushor.2009.09.003.

Karjaluoto, Heikki; Sinisalo, Jaakko; Saraniemi, Saila; Töllinen, Aarne (2015): Barriers to the use of Mobile Sales Force Automation Systems. A Salesperson's Perspective. In Krzysztof Kubacki (Ed.): Ideas in Marketing: Finding the New and Polishing the Old. Cham, 2015. Cham: Springer International Publishing, pp. 625-634. 
Karjaluoto, Heikki; Töllinen, Aarne; Pirttiniemi, Janne; Jayawardhena, Chanaka (2014): Intention to use mobile customer relationship management systems. In Industr Mngmnt \& Data Systems 114 (6), pp. 966-978. DOI: 10.1108/IMDS-11-2013-0480.

Kawahara, Tatsuya; Lee, Chin-Hui; Juang, Biing-Hwang (1996): Key-phrase detection and verification for flexible speech understanding. In : The $4^{\text {th }}$ International Conference on Spoken Language Processing, Philadelphia, PA, USA, October 3-6, 1996.

Kaynama, Shohreh A. (2015): A Conceptual Model To Measure Service Quality Of Online Companies: E-qual. In Harlan E. Spotts, H. Lee Meadow (Eds.): Proceedings of the 2000 Academy of Marketing Science (AMS) Annual Conference. Cham, 2015. Cham: Springer International Publishing, pp. 46-51.

Keller, Thorben; Thiesse, Frédéric; Fleisch, Elgar (2014): Using Dynamic Time Warping to Identify RFID Tag Movement in a Logistics Scenario with and without Additional Process Knowledge. In : Proceedings of the International Conference on Information Systems - Building a Better World through Information Systems, ICIS 2014, Auckland, New Zealand, December 14-17, 2014.

Kemper, Hans-Georg; Wolf, Elke (2002): Iterative Process Models for Mobile Application Systems: A Framework. In : Proceedings of the International Conference on Information Systems, ICIS 2002, Barcelona, Spain, December 15-18, 2002, p. 37. Kim, Hee-Woong; Lee, Gil-Hyung; Pan, Shan Ling (2002): Exploring the Critical Success Factors for Customer Relationship Management and Electronic Customer Relationship Management Systems. In : Proceedings of the International Conference on Information Systems, ICIS 2002, Barcelona, Spain, December 15-18, 2002, p. 93.

Kim, KyungOk Kacy (2015): Measurement of Digital Content Marketing Effectiveness Through Social Media. In Krzysztof Kubacki (Ed.): Ideas in Marketing: Finding the New and Polishing the Old. Cham, 2015. Cham: Springer International Publishing, p. 815 .

Klöckner, Maximilian; Kurpjuweit, Stefan; Velu, Chander; Wagner, Stephan M. (2020): Does Blockchain for 3D Printing Offer Opportunities for Business Model Innovation? In Research Technology Management 63 (4), pp. 18-27. DOI:

10.1080/08956308.2020.1762444.

Koskinen, Ilpo (2003): User-generated content in mobile multimedia: empirical evidence from user studies. In : Proceedings of the 2003 IEEE International Conference on Multimedia and Expo, ICME 2003, 6-9 July 2003, Baltimore, MD, USA, pp. 645-648.

Krenzer, Adrian; Stein, Nikolai; Griebel, Matthias; Flath, Christoph (2019): Augmented Intelligence for Quality Control of Manual Assembly Processes using Industrial Wearable Systems. In : Proceedings of the $40^{\text {th }}$ International Conference on Information Systems, ICIS 2019, Munich, Germany, December 15-18, 2019. 
Krippendorff, Klaus (1989): On the essential contexts of artifacts or on the proposition that" design is making sense (of things)". In Design issues 5 (2), pp. 9-39.

Krishna, Chethana G. (2018): Starbucks Communication Strategies - More Than Just a Cup of Coffee. In IUP Journal of Soft Skills 12 (3), pp. 23-53.

Kull, Alexander J. (2015): Expanding the Scope of Value Co-Creation. In Robinson, Jr., Leroy (Ed.): Marketing Dynamism \& Sustainability: Things Change, Things Stay the Same... Cham, 2015. Cham: Springer International Publishing, p. 166.

Kumar, Akhil (1990): A New Approach for Conflict Resolution and Rule Processing in a Knowledge-Based System. In : Proceedings of the $11^{\text {th }}$ International Conference on Information Systems, ICIS 1990, Copenhagen, Denmark, December 16-19, 1990, p. 43.

Kumar, V.; Chattaraman, Veena; Neghina, Carmen; Skiera, Bernd; Aksoy, Lerzan; Buoye, Alexander; Henseler, Joerg (2013): Data-driven services marketing in a connected world. In Journal of Service Management 24 (3), pp. 330-352. DOI: 10.1108/09564231311327021.

Kurniawati, Kurniawati; Shanks, Graeme G.; Bekmamedova, Nargiza (2013): The Business Impact Of Social Media Analytics. In : $21^{\text {st }}$ European Conference on Information Systems, ECIS 2013, Utrecht, The Netherlands, June 5-8, 2013, p. 48.

Lacka, Ewelina; Yip, Nick K.T. (2018): Revealing the effect of acculturation process on ecommerce acceptance. In Industr Mngmnt \& Data Systems 118 (6), pp. 1251-1265. DOI: 10.1108/IMDS-11-2017-0509.

Lal, Rajiv; Johnson, Scott (2018): Maersk: Betting on Blockchain. In Harvard Business School Cases.

Landry, Timothy D.; Arnold, Todd J.; Suter, Tracy A. (2015): Theoretical Perspectives of Online Community: Managerial Insights and Research Agenda. In Harlan E. Spotts (Ed.): Revolution in Marketing: Market Driving Changes. Cham, 2015. Cham: Springer International Publishing, p. 207.

Legacy, Crystal; Ashmore, David; Scheurer, Jan; Stone, John; Curtis, Carey (2019): Planning the driverless city. In Transport Reviews 39 (1), pp. 84-102. DOI: 10.1080/01441647.2018.1466835.

Lemon, Katherine N.; Verhoef, Peter C. (2016): Understanding customer experience throughout the customer journey. In Journal of Marketing 80 (6), pp. 69-96.

Lindsay, Amber; Kaykas-Wolff, Jascha; Mathwick, Charla (2015): Key Influencers: Locating, Measuring, and Creating Programs to Influence Social Media Influencers. In Dawn R. Deeter-Schmelz (Ed.): Proceedings of the 2010 Academy of Marketing Science (AMS) Annual Conference. Cham, 2015. Cham: Springer International Publishing, p. 1.

Liu, Charles Zhechao; Au, Yoris A.; Choi, Hoon Seok (2012): An Empirical Study of the Freemium Strategy for Mobile Apps: Evidence from the Google Play Market. In : 
Proceedings of the International Conference on Information Systems, ICIS 2012, Orlando, Florida, USA, December 16-19, 2012.

Liu, Sandra S.; Luo, Xueming (2015): Exploratory Research on Integrated Web-Based Knowledge Management in a Customer Contact. In Harlan E. Spotts (Ed.): Creating and Delivering Value in Marketing. Cham, 2015. Cham: Springer International Publishing, p. 89.

Liu, Tsung-Yu; Tan, Tan-Hsu; Chu, Yu-Ling (2007): 2D Barcode and Augmented Reality Supported English Learning System. In : $6^{\text {th }}$ Annual IEEE/ACIS International Conference on Computer and Information Science (ICIS 2007), 11-13 July 2007, Melbourne, Australia, pp. 5-10.

Liu, Xia (2015): Development of a Scale to Measure the Perceived Interactivity of Websites. In Robinson, Jr., Leroy (Ed.): Marketing Dynamism \& Sustainability: Things Change, Things Stay the Same... Cham, 2015. Cham: Springer International Publishing, p. 91. Lo, Louis Yi-Shih; Lin, Sheng Wei (2010): The Effect of Price Presentation, Sales Restrictions, and Social Networks on Consumer eWOM Activities: Two-Phase Validation. In : Proceedings of the International Conference on Information Systems, ICIS 2010, Saint Louis, Missouri, USA, December 12-15, 2010, p. 49.

Löbbecke, Claudia; Powell, Philip (1997): Understanding internet advertising. In : Proceedings of the Eighteenth International Conference on Information Systems, Atlanta, Georgia, USA, December 15-17, 1997, p. 452.

Luke, Robert H. (2015): Characteristics of Successful Telemarketing Associates. In Michael Levy, Dhruv Grewal (Eds.): Proceedings of the 1993 Academy of Marketing Science (AMS) Annual Conference. Cham, 2015. Cham: Springer International Publishing, pp. 261-267.

Maldonado-Guzmán, Gonzalo; Garza-Reyes, Jose Arturo; Pinzón-Castro, Sandra Yesenia; Kumar, Vikas (2017): Barriers to innovation in service SMEs: evidence from Mexico. In Industr Mngmnt \& Data Systems 117 (8), pp. 1669-1686. DOI: 10.1108/IMDS-082016-0339.

Mallen, Bruce (1975): Marketing channels and economic development: A literature overview. In International Journal of Physical Distribution.

Mann, Manveer Kaur; Liu-Thompkins, Yuping; Watson, Ginger S.; Papelis, Yiannis E. (2015): A Multidisciplinary Examination of 3D Virtual Shopping Environments: Effects on Consumer Perceptual and Physiological Responses. In Krzysztof Kubacki (Ed.): Ideas in Marketing: Finding the New and Polishing the Old. Cham, 2015. Cham: Springer International Publishing, pp. 752-755.

Matt, Christian; Hess, Thomas; Benlian, Alexander (2015): Digital Transformation Strategies. In Bus Inf Syst Eng 57 (5), pp. 339-343. DOI: 10.1007/s12599-015-0401-5. 
Mauri, Lara; Cimato, Stelvio; Damiani, Ernesto (2018): A Comparative Analysis of Current Cryptocurrencies. In : Proceedings of the $4^{\text {th }}$ International Conference on Information Systems Security and Privacy, ICISSP 2018, Funchal, Madeira - Portugal, January 2224, 2018, pp. 127-138.

Melancon, Joanna Phillips; Dalakas, Vassilis (2016): Managing Social Consumer Voice: A Structured Abstract. In Kacy K. Kim (Ed.): Celebrating America's Pastimes: Baseball, Hot Dogs, Apple Pie and Marketing? Cham, 2016. Cham: Springer International Publishing, pp. 563-568.

Mentzer, John T.; Vashi, Vidyut; Rieley, Donald (2015): Market Pricing of Real Estate Units: A Knowledge-Based System Approach. In Michael Levy, Dhruv Grewal (Eds.):

Proceedings of the 1993 Academy of Marketing Science (AMS) Annual Conference. Cham, 2015. Cham: Springer International Publishing, pp. 612-615.

Mills, Adam J.; Reynecke, Mignon; Pitt, Leyland; Campbell, Colin (2015): Drawing Meaning from Online User Discussions About Brands: A Study of Comments in Response to Luxury Advertisements on YouTube. In Mary Conway Dato-on (Ed.): The Sustainable Global Marketplace. Cham, 2015. Cham: Springer International Publishing, p. 398. Mohammed, Rafi (2015): How Walmart Can Start Competing Online. In Harvard Business Review Digital Articles, pp. 2-4.

Morgan, Amy J.; Attaway, Jill S. (2015): Expanding the Retail Marketplace: Understanding the Internet Shopper. In Elizabeth J. Wilson, Hair, Jr., Joseph F (Eds.): Proceedings of the 1997 Academy of Marketing Science (AMS) Annual Conference. Cham, 2015. Cham: Springer International Publishing, pp. 290-294.

Morgan, Todd; Obal, Michael (2016): Customer Participation in New Product Development and New Product Performance: The Moderating Role of Expertise. In Kacy K. Kim (Ed.): Celebrating America's Pastimes: Baseball, Hot Dogs, Apple Pie and Marketing? Cham, 2016. Cham: Springer International Publishing, p. 465.

Mulier, Thomas (2019): H\&M Jumps Most Since March on Store-Expansion Cut, Online Growth. In Bloomberg.com, N.PAG-N.PAG.

Munnukka, Juha; Maity, Devdeep (2018): Exploring the Role of Audience Participation and Para-social Interaction on Endorsement Effectiveness in Vlogs: An Abstract. In Nina Krey, Patricia Rossi (Eds.): Back to the Future: Using Marketing Basics to Provide Customer Value. Cham, 2018. Cham: Springer International Publishing, p. 213.

Muro, Mark; Maxim, Robert; Whiton, Jacob (2019): Automation and artificial intelligence: How machines are affecting people and places.

Murray, Lynn M.; Maceli, Kristen (2017): Using Online Discussion Forums to Improve Formative Assessment: An Extended Abstract. In Maximilian Stieler (Ed.): Creating 
Marketing Magic and Innovative Future Marketing Trends. Cham, 2017. Cham:

Springer International Publishing, pp. 359-362.

Nakhata, Chinintorn (2015): No Clipping, No Printing Required: Antecedents of Consumers'

Intention to use SMS Coupons. In Mary Conway Dato-on (Ed.): The Sustainable Global

Marketplace. Cham, 2015. Cham: Springer International Publishing, p. 170.

Nel, Jacques; Boshoff, Christo; Raleting, Tsietsi (2015): Technology Cluster Effect as

Moderator in the Technology Acceptance Model: The Case of Text Messaging and Wig

Mobile Banking Adoption. In Mary Conway Dato-on (Ed.): The Sustainable Global

Marketplace. Cham, 2015. Cham: Springer International Publishing, p. 240.

Odell, Patty (2018): IHOP Flips "P" for "b" and Social Goes Wild. In Promotional Marketing,

p. 1.

Oh, Jeong-ha; Susarla, Anjana; Tan, Yong (2008): Diffusion of User-Generated Content in a

Social Network Structure. In : Proceedings of the International Conference on

Information Systems, ICIS 2008, Paris, France, December 14-17, 2008, p. 199.

Paluch, Stefanie (2015): Implications of Remote Service Delivery on Customer Relationship

Management: A Qualitative Study in a B2B-Setting. In Dawn R. Deeter-Schmelz (Ed.):

Proceedings of the 2010 Academy of Marketing Science (AMS) Annual Conference.

Cham, 2015. Cham: Springer International Publishing, p. 4.

Paramonov, Viacheslav; Fedorov, Roman; Ruzhnikov, Gennagy M.; Shumilov, Alexandr S.

(2013): Web-Based Analytical Information System for Spatial Data Processing. In :

Information and Software Technologies - $19^{\text {th }}$ International Conference, ICIST 2013,

Kaunas, Lithuania, October 2013. Proceedings, pp. 93-101.

Pitt, Christine; Eriksson, Theresa; Dabirian, Amir; Vella, Joseph (2018): Elementary, My Dear

Watson: The Use of Artificial Intelligence in Marketing Research: An Abstract. In Nina

Krey, Patricia Rossi (Eds.): Boundary Blurred: A Seamless Customer Experience in

Virtual and Real Spaces. Cham, 2018. Cham: Springer International Publishing, p. 325.

Popkin, Helen A. S. (2018): Elon Musk’s Twitter Account Is Tesla’s \$40 Millon Marketing

Platform. 'Worth It'. In Forbes.com, p. 8.

Poushneh, Atieh (2017): The Role of Customer Readiness in User's Willingness to Use

Augmented Reality: An Abstract. In Maximilian Stieler (Ed.): Creating Marketing

Magic and Innovative Future Marketing Trends. Cham, 2017. Cham: Springer

International Publishing, p. 529.

Prabhaker, Paul R.; Sheehan, Michael J.; Coppett, John I. (1997): The power of technology in business selling: call centers. In Jnl of Bus \& Indus Marketing.

Prahalad, Coimbatore K.; Ramaswamy, Venkat (2004): Co-creation experiences: The next practice in value creation. In Journal of interactive marketing 18 (3), pp. 5-14. 
Püschel, Tim; Neumann, Dirk (2009): Management of Cloud Infastructures: Policy-Based

Revenue Optimization. In : Proceedings of the International Conference on Information Systems, ICIS 2009, Phoenix, Arizona, USA, December 15-18, 2009, p. 178.

Ranganathan, C.; Dadalt, Peter (2001): Dot-Com Deals: An Empirical Investigation of Value Creation in Internet Related Acquisitions. In : Proceedings of the International Conference on Information Systems, ICIS 2001, December 16-19, 2001, New Orleans, Louisiana, USA, pp. 405-406.

Rebholz, Jenny S. (2019): Walmart's “Smart Assistants”. In Design: Retail 31 (5), p. 22. Reid, Edna (2000): Web-based data collection for the analysis of hidden relationships (Web mining of hypertext links). In : Proceedings of the Twenty-First International Conference on Information Systems, ICIS 2000, Brisbane, Australia, December 10-13, 2000, pp. 739-740.

Ricciardi, Francesca; Zardini, Alessandro; Rossignoli, Cecilia (2017): Organizational integration of the IT function: A key enabler of firm capabilities and performance. In Journal of Innovation \& Knowledge 3 (3), pp. 93-107. DOI: 10.1016/j.jik.2017.02.003.

Rieger, Keith; Davis, Donna F.; Golicic, Susan L. (2015): Innovative Information Technology Competence: The Concept and its Role in Decision Making. In Harlan E. Spotts (Ed.): Assessing the Different Roles of Marketing Theory and Practice in the Jaws of Economic Uncertainty. Cham, 2015. Cham: Springer International Publishing, p. 85. Robson, Karen; Pitt, Leyland; Kietzmann, Jan; Halvorson, Wade; Wallstrom, Asa (2016): Wearable Technology: Trends and Opportunities for Organizations. In Kacy K. Kim (Ed.): Celebrating America's Pastimes: Baseball, Hot Dogs, Apple Pie and Marketing? Cham, 2016. Cham: Springer International Publishing, p. 801.

Rust, Roland T. (2020): The future of marketing. In International Journal of Research in Marketing 37 (1), pp. 15-26. DOI: 10.1016/j.ijresmar.2019.08.002.

Saad, Walid; Bennis, Mehdi; Chen, Mingzhe (2019): A vision of 6G wireless systems: Applications, trends, technologies, and open research problems. In IEEE Network 34 (3), pp. 134-142.

Sarda, N. L. (1987): Design of an Information System using a Historical Database Management System. In : Proceedings of the $8^{\text {th }}$ International Conference on Information Systems, ICIS 1987, Pittsburgh, Pennsylvania, USA, 1987, p. 30.

Saura, José Ramón; Palos-Sánchez, Pedro; Cerdá Suárez, Luis Manuel (2017): Understanding the Digital Marketing Environment with KPIs and Web Analytics. In Future Internet 9 (4), p. 76. DOI: 10.3390/fi9040076.

Sautter, Sarah Jo; Lindquist, Jay D. (2015): Exploring Print Ads and Web Sites Target Market and Approach Match-Ups: Interactive Video Games and Facial Cosmetics. In John B. Ford, Honeycutt, Jr., Earl D (Eds.): Proceedings of the 1998 Academy of Marketing 
Science (AMS) Annual Conference. Cham, 2015. Cham: Springer International Publishing, pp. 174-178.

Schmitt, Bernd (1999): Experiential marketing. In Journal of Marketing Management 15 (1-3), pp. 53-67.

Schocken, Shimon (1990): Panel 16: Business Applications of Neural Networks: Problems and Opportunities. In : Proceedings of the $11^{\text {th }}$ International Conference on Information Systems, ICIS 1990, Copenhagen, Denmark, December 16-19, 1990, p. 10.

Schön, Dominik (2019): The Influence of Automated Planning on the Task Performance of Process Modelers. In : Proceedings of the $40^{\text {th }}$ International Conference on Information Systems, ICIS 2019, Munich, Germany, December 15-18, 2019.

Segev, Sigal; Fiske, Rosanna; Villar, Maria Elena (2015): Understanding Bloggers: Opinion Leadership and Motivations to Use Blogs Among Bloggers and Blog Readers. In Robinson, Jr., Leroy (Ed.): Marketing Dynamism \& Sustainability: Things Change, Things Stay the Same... Cham, 2015. Cham: Springer International Publishing, p. 123. Shao, Zhen; Zhang, Lin; Chen, Kuanchin; Zhang, Chenliang (2020): Examining user satisfaction and stickiness in social networking sites from a technology affordance lens: uncovering the moderating effect of user experience. In Industr Mngmnt \& Data Systems 120 (7), pp. 1331-1360. DOI: 10.1108/IMDS-11-2019-0614.

Sheth, Jagdish; Sisodia, Rajendra (2012): The 4 A's of marketing: Creating value for customer, company and society: Routledge.

Sheth, Jagdish N.; Sisodia, Rajendra S.; Sharma, Arun (2000): The antecedents and consequences of customer-centric marketing. In J. of the Acad. Mark. Sci. 28 (1), pp. 55-66.

Simula, Henri; Töllmen, Aarne; Karjaluoto, Heikki (2015): Facilitating Innovations and Value Co-Creation in Industrial B2B Firms by Combining Digital Marketing, Social Media and Crowdsourcing. In Robinson, Jr., Leroy (Ed.): Marketing Dynamism \& Sustainability: Things Change, Things Stay the Same... Cham, 2015. Cham: Springer International Publishing, pp. 254-263.

Singh, Anna; Hess, Thomas (2017): How Chief Digital Officers promote the digital transformation of their companies. In MIS Quarterly Executive 16 (1).

Sisodia, Rajendra S. (2006): Does marketing need reform?: Fresh perspectives on the future: ME Sharpe.

Srinivasan, Suraj; Chen, Wilbur (2019): Research: Investors Reward Companies That Talk Up Their Digital Initiatives. In Harvard Business Review Digital Articles, pp. 2-5.

Stein, Nikolai; Walter, Benedikt; Flath, Christoph (2019): Towards Open Production: Designing a marketplace for 3D-printing capacities. In : Proceedings of the $40^{\text {th }}$ International 
Conference on Information Systems, ICIS 2019, Munich, Germany, December 15-18, 2019.

Subramanyam, Ramanath; Krishnan, Mayuram S. (2001): Business Value of IT-Enabled Call Centers: An Empirical Analysis. In : Proceedings of the International Conference on Information Systems, ICIS 2001, December 16-19, 2001, New Orleans, Louisiana, USA, pp. 55-64.

Sudbeck, David J. (2015): Two Strategies of Consumer Search: How Customers find ECommerce Sites. In Melissa Moore, Robert S. Moore (Eds.): New Meanings for Marketing in a New Millennium. Cham, 2015. Cham: Springer International Publishing, pp. 156-158.

Sun, Qin; Spears, Nancy (2015): Consumer Evaluation of Search Advertising and Search Engine Effectiveness: The Role of Frustration. In Mary Conway Dato-on (Ed.): The Sustainable Global Marketplace. Cham, 2015. Cham: Springer International Publishing, p. 365 .

Swain, Ajaya Kumar; Cao, Qing (2014): Impact of Online Firm Generated Content (FGC) on Supply Chain Performance: An Empirical Analysis. In : $47^{\text {th }}$ Hawaii International Conference on System Sciences, HICSS 2014, Waikoloa, HI, USA, January 6-9, 2014, pp. 561-573.

Swilley, Esther; Cowart, Kelly O. (2015): Extending Flow Theory To Mobile Shopping. In Krzysztof Kubacki (Ed.): Ideas in Marketing: Finding the New and Polishing the Old. Cham, 2015. Cham: Springer International Publishing, p. 179.

Taecharungroj, Viriya (2017): Starbucks' marketing communications strategy on Twitter. In Journal of Marketing Communications 23 (6), pp. 552-571. DOI:

10.1080/13527266.2016.1138139.

Taylor, David G.; Voelker, Troy A.; Pentina, Iryna (2015): 'I will if You will': The Effect of Social Network Ties on the Adoption of Mobile Applications. In Mary Conway Datoon (Ed.): The Sustainable Global Marketplace. Cham, 2015. Cham: Springer International Publishing, p. 239.

Töllinen, Aarne; Karjaluoto, Heikki; Jayawardhena, Chanaka (2015): The Intention of The Sales Force To Use Mobile CRM: Model Development and Validation. In Krzysztof Kubacki (Ed.): Ideas in Marketing: Finding the New and Polishing the Old. Cham, 2015. Cham: Springer International Publishing, p. 180.

Treiblmaier, Horst; Dickinger, Astrid (2006): The Importance of Previous Experience for the Trial of Mobile Self-Service Technologies. In : Proceedings of the International Conference on Information Systems, ICIS 2006, Milwaukee, Wisconsin, USA, December 10-13, 2006, p. 49. 
Tremblay, Monica Chiarini; Kohli, Rajiv; Forsgren, Nicole; Grover, Varun; Abassi, Ahmed; Hevner, Alan R.; Rapaport, Roy (2018): Will Artificial Intelligence Automate Theory Building? Are there Lessons for Academia from Practice? In : Proceedings of the International Conference on Information Systems - Bridging the Internet of People, Data, and Things, ICIS 2018, San Francisco, CA, USA, December 13-16, 2018.

Tuten, Tracy; Ashley, Christy; Oliver, Jason (2015): Social Media Applications for Marketing Educators. In Mary Conway Dato-on (Ed.): The Sustainable Global Marketplace. Cham, 2015. Cham: Springer International Publishing, p. 4.

Ulusu, Yeşim; Durmuş, Beril; Yurtkoru, E. Serra (2015): Social Networking as a Marketing Tool. In Dawn R. Deeter-Schmelz (Ed.): Proceedings of the 2010 Academy of Marketing Science (AMS) Annual Conference. Cham, 2015. Cham: Springer International Publishing, pp. 257-261.

Vakrat, Yaniv; Seidmann, Abraham (1999): Can online auctions beat online catalogs? In :

Proceedings of the Twentieth International Conference on Information Systems, ICIS 1999, Charlotte, North Carolina, USA, December 13-15, 1999, pp. 132-143.

van Waterschoot, Walter; van den Bulte, Christophe (1992): The 4P classification of the marketing mix revisited. In Journal of Marketing 56 (4), pp. 83-93.

Vassileva, Bistra (2017): Marketing 4.0: How Technologies Transform Marketing Organization. In Óbuda University e-Bulletin 7, pp. 47-56.

Verhoef, Peter C.; Leeflang, Peter S.H. (2009): Understanding the Marketing Department's Influence within the Firm. In Journal of Marketing 73 (2), pp. 14-37. DOI: 10.1509/jmkg.73.2.14.

Verhoef, Peter C.; Leeflang, Peter S.H. (2010): Getting Marketing back into the boardroom: The influence of the marketing department in companies today. In GfK Marketing Intelligence Review 2 (1), pp. 34-41. DOI: 10.2478/gfkmir-2014-0069.

Veth, Ton; Markus, M. Lynne; Scheer, August-Wilhelm; Kumar, Kuldeep; Wortmann, Hans (1998): Acquiring an implementing ERP: the view from business and academia (panel session). In : Proceedings of the Nineteenth International Conference on Information Systems, ICIS 1998, Helsinki, Finland, December 13-16, 1998, pp. 410-411.

Wang, Fang; Menon, Kalyani; Ranaweera, Chatura; Zhang, Xiao-Ping (2016): Online Product Ratings: Dynamic Trends and Diagnosticity Assessment Explanation. In Michael W. Obal, Nina Krey, Christian Bushardt (Eds.): Let's Get Engaged! Crossing the Threshold of Marketing's Engagement Era. Cham, 2016. Cham: Springer International Publishing, p. 391.

Wang, Ze; Arndt, Aaron D.; Singh, Surendra N.; Biernat, Monica (2015): Linguistic Stereotyping in Call Centers. In Robinson, Jr., Leroy (Ed.): Proceedings of the 2008 
Academy of Marketing Science (AMS) Annual Conference. Cham, 2015. Cham:

Springer International Publishing, pp. 71-75.

Weinmann, Markus; Schneider, Christoph; Robra-Bissantz, Susanne (2013): User Modeling Of

Online Consumers: Between-Gender Differences In Click Path Data. In : $21^{\text {st }}$ European

Conference on Information Systems, ECIS 2013, Utrecht, The Netherlands, June 5-8, 2013, p. 188.

Wiedmann, Klaus-Peter; Mettenheim, Walter von (2020): The Interaction of Consumer, Endorser, and Brand Personality in Social Influencer Marketing: An Abstract. In Shuang Wu, Felipe Pantoja, Nina Krey (Eds.): Marketing Opportunities and Challenges in a Changing Global Marketplace. Cham, 2020. Cham: Springer International Publishing, pp. 359-360.

Williams, Miranda; Hodges, Nancy (2016): Are Sponsored Blog Posts a Good Thing?

Exploring the Role of Authenticity in the Fashion Blogosphere. In Kacy K. Kim (Ed.):

Celebrating America's Pastimes: Baseball, Hot Dogs, Apple Pie and Marketing? Cham, 2016. Cham: Springer International Publishing, pp. 157-162.

Wu, Ling; Liu, Sheng; Zhao, Baoling; Wu, Weinan; Zhu, Baozhong (2019): The research of the application of the binary search algorithm of RFID system in the supermarket shopping information identification. In EURASIP J. Wireless Comm. and Networking 2019, p. 27. DOI: 10.1186/s13638-019-1343-2.

Wu, Ya-Ling; Li, Eldon Y. (2018): Marketing mix, customer value, and customer loyalty in social commerce. In Internet Research.

Xu, Jennifer Jie; Chau, Michael (2006): Mining Communities of Bloggers: A Case Study on Cyber-Hate. In : Proceedings of the International Conference on Information Systems, ICIS 2006, Milwaukee, Wisconsin, USA, December 10-13, 2006, p. 11.

Xu, Sean Xin; Zhang, Xiaoquan (2009): How Do Social Media Shape the Information

Environment in the Financial Market? In : Proceedings of the International Conference on Information Systems, ICIS 2009, Phoenix, Arizona, USA, December 15-18, 2009, p. 56.

Yada, Katsutoshi; Matsumura, Naohiro; Ohno, Kosuke; Tamura, Hiroshi (2015): Does WEB Log Data Reveal Consumer Behavior? The Case of Analysis for an Internet Mall. In Harlan E. Spotts (Ed.): Revolution in Marketing: Market Driving Changes. Cham, 2015. Cham: Springer International Publishing, pp. 256-262.

Yang, Kenneth C. C. (2015): Consumers' Attitudes Toward Regulation of Internet Auction Sites: A Third Person Effect Perspective. In Harlan E. Spotts (Ed.): Marketing, Technology and Customer Commitment in the New Economy. Cham, 2015. Cham: Springer International Publishing, p. 20. 
Yang, Kenneth C. C.; Chye, Gerald Ng Soon; Fern, Jeannie Chan Su; Kang, Yowei (2015): Understanding the Adoption of Mobile Commerce in Singapore with the Technology Acceptance Model (TAM). In Harlan E. Spotts (Ed.): Assessing the Different Roles of Marketing Theory and Practice in the Jaws of Economic Uncertainty. Cham, 2015. Cham: Springer International Publishing, pp. 211-215.

Yang Shuiqing; Zhou Yusheng; Yao Jianrong; Chen Yuangao; Wei June (2019): Understanding online review helpfulness in omnichannel retailing. In Industr Mngmnt \& Data Systems 119 (8), pp. 1565-1580. DOI: 10.1108/IMDS-10-2018-0450.

Yohn, Denise Lee (2017): Walmart Won't Stay on Top If Its Strategy Is “Copy Amazon”. In Harvard Business Review Digital Articles, pp. 2-4.

Yoo, Byungjoon; Choudhary, Vidyanand; Mukhopadhyay, Tridas (2001): Neutral Versus Biased Marketplaces: A Comparison of Electronic B2B Marketplaces with Different Ownership Structures. In : Proceedings of the International Conference on Information Systems, ICIS 2001, December 16-19, 2001, New Orleans, Louisiana, USA, pp. 121122.

Yuksel, Mujde; Milne, George R. (2016): Download and Run: An Investigation of Consumer Empowerment Through the Effects of Digital Self-Tracking. In Kacy K. Kim (Ed.): Celebrating America's Pastimes: Baseball, Hot Dogs, Apple Pie and Marketing? Cham, 2016. Cham: Springer International Publishing, p. 203.

Zahay, Debra (2015): Successful B2B Customer Database Management. In Harlan E. Spotts (Ed.): Revolution in Marketing: Market Driving Changes. Cham, 2015. Cham: Springer International Publishing, p. 110.

Zhang, Wenping; Lau, Raymond Y. K.; Li, Chunping (2014): Adaptive Big Data Analytics for Deceptive Review Detection in Online Social Media. In : Proceedings of the International Conference on Information Systems - Building a Better World through Information Systems, ICIS 2014, Auckland, New Zealand, December 14-17, 2014. Zhou, Jilei (2017): Data Mining for Individual Consumer Credit Default Prediction under Ecommence Context: A Comparative Study. In : Proceedings of the International Conference on Information Systems - Transforming Society with Digital Innovation, ICIS 2017, Seoul, South Korea, December 10-13, 2017.

Zhu, Ying; Meyer, Jeffrey (2017): Getting in touch with your thinking style: How touchscreens influence purchase. In Journal of Retailing and Consumer Services 38, pp. 51-58. DOI: 10.1016/j.jretconser.2017.05.006.

Zugelder, Michael T.; Clarke, Irvine; Flaherty, Theresa B. (2015): Emerging Jurisdictional Issues in Online Marketing. In Harlan E. Spotts (Ed.): Proceedings of the 2002 Academy of Marketing Science (AMS) Annual Conference. Cham, 2015. Cham: Springer International Publishing, p. 103. 
Information Technology and Marketing - An Important Partnership for Decades

Zvilichovsky, David; Inbar, Yael; Barzilay, Ohad (2013): Playing Both Sides of the Market:

Success and Reciprocity on Crowdfunding Platforms. In : Proceedings of the

International Conference on Information Systems, ICIS 2013, Milano, Italy, December $15-18,2013$ 